\title{
İlköğretim Matematik Öğretmen Adaylarının TPAB Güven Algılarının İncelenmesi *
}
Investigation of TPACK Confidence Perception of Prospective Elemen- tary Mathematics Teachers

DOI = http://dx.doi.org/10.17556/jef.04990

\author{
Kübra AÇIKGÜL**, Recep ASLANER ***
}

\section{Özet}

$\mathrm{Bu}$ çalışmanın amacı matematik öğretmen adaylarının Teknolojik Pedagojik Alan Bilgisi (TPAB) güven düzeylerini belirlemek ve güven düzeylerinin cinsiyet, sınıf düzeyi, bilgisayar sahibi olma, bilgisayar kullanma sıklığı, teknoloji kullanma düzeyi değişkenlerine göre farklılaşıp farklılaşmadığını incelemektir. Araştırma betimsel ve ilişkisel tarama modelleri ile desenlenmiştir. Araştırmanın çalışma grubu farklı sınıf düzeylerinde öğrenim gören 527 ilköğretim matematik öğretmen adayından oluşmuştur $($ Kadın= 355 , Erkek= 170 ve Kayıp veri=2). Araştırmanın verileri "Teknolojik Pedagojik Alan Bilgisi Güven Ölçeği”" ile toplanmıștır. Bu çalışmada, öğretmen adaylarının TPAB konusunda kendilerine "oldukça" güvendikleri belirlenmiştir. Bu çalışma aynı zamanda öğretmen adaylarının TPAB güvenlerinin cinsiyet ve sınıf düzeyi değişkenine gore değişmediğini göstermiştir. Bunun yanı sıra, öğretmen adaylarının TPAB güven düzeylerinin bilgisayar sahibi olma, bilgisayar kullanım sıklığı ve teknoloji kullanma düzeyi değişkenleri açısından anlamlı olarak değiştiği belirlenmiştir.

Anahtar Sözcük: TPAB, Matematik Öğretmen Adayı, Güven

\footnotetext{
Abstract

The aims of study were to determine prospective elementary mathematics teachers' confidence perception regarding Technological Pedagogical Content Knowledge (TPACK) and to examine whether prospective teachers' TPACK confidence differed with respect to gender, grade levels, computer related variables. This research was designed using descriptive and correlational survey model. The

* Bu çalışma, 6-8. Şubat 2014 tarihleri arasında düzenlenen III. European Conference on Social and Behavioral Conference' ta sözlü bildiri olarak sunulmuştur.

** Aeş. Grv., İnönü Üniversitesi, kubra. acikgul@inonu. edu. tr

*** Prof. Dr., İnönü Üniversitesi, recep. aslaner@inonu. edu. tr
} 
study group consisted of 527 prospective teachers. Data were collected through "TPACK Confidence Scale". In the study it was found prospective teachers felt quite confident. This study showed that the prospective mathematics teachers' TPACK confidence didn't differ with regard to gender and grade levels and prospective teachers' confidence levels differed significantly between computer ownership, computer usage frequency and level of use of technology.

Keywords: TPACK, Prospective Mathematics Teacher, Confidence

\section{Giriş}

"Son yıllarda bilişim teknolojileri alanındaki hızlı gelişmeler eğitim ortamlarında öğrenme- öğretme sürecine teknoloji desteğini zorunlu hale getirmiş ve bilişim teknolojileri ile öğrenme ortamları bütünleşmeye başlamıştır" (Ekici, Taşkın Ekici ve Kara, 2012, s. 54). $\mathrm{Bu}$ durum öğretmenlere ve öğretimlerine önemli yenilikler getirmiş (Şahin, 2011) ve eğitimde teknoloji entegrasyonu öğretmen eğitiminde önemli bir ilgi haline gelmiştir (Agyei ve Vooght, 2012).

Etkili öğretim etkili teknoloji kullanımını gerektirmektedir (Ertmer ve Ottenbreit-Leftwich, 2010). Eğitim ortamlarında teknoloji kullanımının bir ihtiyaca dönüşmesi öğretmenlerin sahip olmas1 gereken niteliklerinde değişmesine neden olmuştur (Yavuz Konakman, Yanpar Yelken ve Sancar Tokmak, 2013). Teknolojinin katkılarına vurgu olarak, öğretmenlerin etkililiklerini artıracak ve genişletecek şekilde teknoloji kullanmaları öngörülmektedir (Ertmer ve Ottenbreit-Leftwich, 2010). Bu bağlamda öğretmenlerden teknolojiyi kullanacak bilgi ve becerilere sahip olmaları (Çakır ve Yıldırım, 2009; Gülbahar, 2008; Karal ve Berigel, 2006) ve teknolojiyi kendi özel müfredatlarına etkili bir şekilde entegre etmeleri istenmektedir (Albion, 1999; Hicks, 2006).

Öğretmenlerden beklenen özelliklerin yanı sıra öğretim içerisine teknolojiyi başarılı bir şekilde birleştirmek o kadar kolay değildir (Jang ve Tsai, 2012). Yapılan çalışmalar öğretmenlerin teknolojiyi derslerinde beklentiler doğrultusunda kullanmadığını göstermektedir (Brush vd, 2003; Ertmer, Addison, Lane, Ross ve Woods, 1999; Ertmer ve Ottenbreit-Leftwich, 2010).

Teknoloji ile öğretim karmaşıktır (Koehler ve Mishra, 2009) ve teknolojinin etkin kullanımı, gerekli donanımın montajı ve yazılımların yüklenmesinden ibaret değildir (Armstrong vd., 2005). Teknoloji kullanılarak yapılacak iyi bir öğretimin merkezinde 
teknoloji, içerik ve pedagoji olmak üzere 3 temel bileşen ve bu bileşenler arasındaki ilişkiler vardır (Koehler ve Mishra, 2009).

Koehler vd., (2004) bu bileşenler arasındaki ilişkiye dikkat çekerek teknoloji entegrasyonu sürecinde yaşanan sıkıntıların bu süreci geliştirmek veya anlamak için gerekli olan teorik çerçeveler ve modeller yoluyla giderilebileceğini ileri sürmüşlerdir. Bu doğrultuda literatürde eğitimcilere teknoloji kullanımlarında rehber olacak ve değerlendirmeye yardımcı olabilecek bir çok teknoloji entegrasyon modeli ve çerçevesi yer almaktadır (Garaham vd, 2009). Bu modellerden biride Koehler ve Mishra (2005) tarafindan ortaya koyulan “Teknolojik Pedagojik Alan Bilgisi” (TPAB) dir. TPAB çerçevesi öğretim sürecinde etkili bir teknoloji entegrasyonu için öğretmen yeterliklerine odaklanan modellerden biridir (Yurdakul Kabakçı vd., 2012).

\section{Teknolojik Pedagojik Alan Bilgisi (TPAB)}

Teknolojik Pedagojik Alan Bilgisi (TPAB), etkili bir teknoloji entegrasyonu için gerekli olan öğretmen bilgisini anlamak amaciyla bir dizi deneysel tasarım (design experiments) sonucu geliştirilmiş teorik bir çerçevedir (Koehler, Mishra, Hershey ve Peruski, 2004; Koehler, Mishra ve Yahya, 2004; Koehler ve Mishra, 2005; Koehler, Mishra ve Yahya, 2007; Mishra ve Koehler, 2006). Kuramsal anlamda ise Shulman'ın tanımladığı alan bilgisi ve pedagojik bilgi alanlarının kesişimlerinden oluşan Pedagojik Alan Bilgisi (PAB) üzerine inşa edilmiştir (Agyei ve Voogt, 2012; Archambault ve Crippen, 2009; Erdoğan ve Şahin, 2010; Graham vd., 2009; Koehler vd., 2004; Koehler ve Mishra, 2005; Koehler vd., 2007; Jang ve Tsai, 2012; Schmidt vd., 2009).

TPAB, öğretimin içerisine teknolojiyi entegre etmeleri için öğretmenlerin sahip olması gereken bilgi türleri olarak pedagoji, alan ve teknoloji bilgisinin kesişimini ele alan bir yapıdır (Abbitt, 2011). $\mathrm{Bu}$ çerçeve ile öğretmenlerin teknoloji hakkında ne bilmesi gerektiğini içeren bir yol çizilmeye çalışılmıştır (Koehler ve Mishra, 2005). TPAB'ın merkezinde bulunan etkileşimsel yapılanmayla birlikte teknoloji, pedagoji ve alan bilgisi ve bunların kesişiminden oluşan toplam yedi bilgi alanı ortaya çıkmıştır: Alan Bilgisi, Pedagoji Bilgisi, Teknoloji Bilgisi, Pedagojik Alan Bilgisi, Teknolojik Alan Bilgisi, 
Teknolojik Pedagoji Bilgisi ve Teknolojik Pedagojik Alan Bilgisi (Agyei ve Voogt 2012; Koehler vd,, 2004; Koehler ve Mishra, 2005, 2008, 2009; Mishra ve Koehler, 2006; Schmidt vd, 2009).

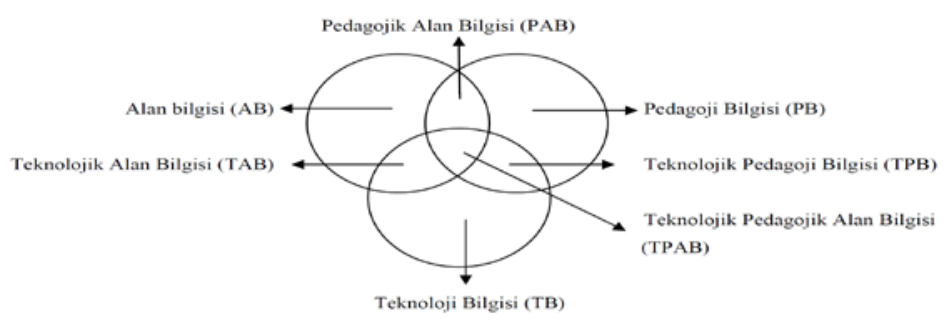

Şekil 1. TPAB Çerçevesi (Mishra ve Koehler, 2006, s. 1025 'ten uyarlanmıştır)

Son dönemlerde birçok eğitim teknoloğu teknolojinin pedagojik kullanımının konu alanı tarafından güçlü bir şekilde etkilendiğinin farkına varmıştır (Graham vd., 2009). Etkili bir teknoloji entegrasyonunda içerik ve pedagojinin birbirine bağlı olması gerektiği inancı öğretmenlerin teknoloji ile ilgili deneyimlerinin farklı içerik alanlarına özgü olması gerektiğini göz önüne getirmiştir (Schmidt vd, 2009). Bu doğrultuda teknolojik pedagojik alan bilgisi ile ilgili çalışmaların belli bir alanın özelliklerini göz önünde bulundurarak incelenmesi gerekmektedir. Teknolojide yaşanan gelişmelerim matematik eğitimini de etkilemesi, ancak diğer alanlarda olduğu gibi bu gelişime paralel olarak teknolojinin matematik öğretmenleri tarafindan beklenen düzeyde kullanılmaması (Agyei \& Voogt, 2011a,b; Alagic ve Pelenz, 2006) dikkate alınarak bu çalışmada matematik öğretmen adaylarının TPAB düzeylerinin incelenmesi önemli görülmüştür.

\section{Öğretmen Adaylarının TPAB Düzeylerinin Ölçülmesi}

Öğretmen bilgisinin TPAB çerçevesi içerisinde ele alınmasıyla belirli bir içerik alanında TPAB'1 ölçmek için yöntemler geliştirmek önemli görülmüştür (Graham vd, 2009). Bu bağlamda literatürde bu kuramsal çerçeveden hareketle öğretmen adayları üzerinde ölçümler yapmak amacıyla çeşitli yaklaşımlar belirlenmiştir. $\mathrm{Bu}$ 
araştırmaların çoğunda ölçekler/anketler geliştirilmiş ve öğretmen adaylarının TPAB düzeyleri belirlenmeye çalışılmıştır (Abbitt, 2011; Archambault ve Crippen, 2009; Baran, Chuang ve Thompson, 2011; Chai, Koh ve Tsai, 2010, 2011; Graham vd, 2009; Koh, Chai ve Tsai, 2010; Lee ve Tsai, 2010; Jang ve Tsai, 2012; Schmidt vd, 2009; Şahin, 2011).

TPAB çerçevesi etkili teknoloji entegrasyonu için belli bir içerik alanında uygun pedagoji ile teknolojiyi birleştirebilmelerine ilişkin öğretmen bilgilerine odaklanmaktadır. Bu bağlamda TPAB bir bilgi alanını işaret etse de ölçek/anket gibi ölçme araçlarıyla toplanacak verilerin bilgiden çok algıları yansıttığı düşünülmektedir. Nitekim TPAB düzeyini belirlemeye yönelik literatürde yer alan çalışmalar bu düşünceyi desteklemektedir. Örneğin Koehler ve Mishra (2005) tarafından geliştirilen TPAB anketinde araştırmacılar katılımcıların algılarından yola çıkmışlardır. Benzer şekilde Koh vd., (2010) ve Koh ve Sing (2011) Singapurda bulunan öğretmen adaylarının TPAB düzeylerini belirlemek amacıyla yaptıkları çalışmalarında elde ettikleri puanları öğretmen adaylarının alg1 düzeyleri olarak ele almışlardır. Archambault ve Barnett (2010) ölçek kullanarak doğrudan gözlemlenen davranışları ölçemedikleri için katılımcıların kendi bilgi düzeylerini nasıl algıladıklarını sorduklarını belirtmişlerdir.

Öğretmenlerin algısı dolaylı olarak öğrenme ve öğretme çıktılarını etkilemektedir (Trigwell, Prosser ve Waterhouse, 1999). Bu nedenle teknoloji entegrasyon sürecinde öğretmenlerin sahip oldukları bilgiler kadar bilgilerine ilişkin algılarını belirlemenin önemli olduğu düşünülmektedir. Literatür incelendiğinde araştırmacıların öğretmenlerin TPAB algısını çeşitli yapılar altında incelendiği belirlenmiştir. Çalışmaların birçoğu öğretmenlerin TPAB algısını öz yeterlik yapısı altında ele almışlardır (Gömleksiz ve Fidan, 2011; Kazu ve Erten, 2011; Kaya, Özdemir, Emre ve Kaya, 2011; Yavuz Konokman vd., 2013). Diğer taraftan TPAB'1 güven algısı olarak inceleyen araştırmalarda mevcuttur (Doukakis vd, 2010; Graham vd, 2009; Sancar Tokmak, Yavuz Konokman ve Yanpar Yelken, 2013; Kaya, Emre ve Kaya, 2010).

Teknoloji entegrasyon sürecinde öğretmenlerin kendilerine güvenmelerinin oldukça önemli olduğu düşünülmektedir. Çünkü bir öğretmenin teknoloji kullanımı konusunda sahip olduğu güven sınıfta teknolojiyi etkili bir şekilde kullanımını etkileyebilir (Christanse, 
2002). Yani teknoloji becerisi gerekli olmasına rağmen eğer öğretmenler öğrencilerinin öğrenmelerini desteklemek için kendilerine güvenmiyorlarsa bu bilgi yeterli değildir (Ertmer ve OttenbreitLeftwich, 2010). Bu nedenle öğretmen ve öğretmen adaylarının, öğrencilere evrensel bir eğitim ve öğretim yapabilmeleri için gelişen yeni nesil web teknolojilerini eğitime entegre etmeleri, bu teknolojileri derslerinde hem kullanmaları hem de kullandırtmaları ve bu teknolojileri kullanmada da öncelikle kendilerine güvenmeleri gerekmektedir (Akgün, 2013). Buna karşın birçok öğretmen teknolojiyi nasıl yapabilirim sorusuyla başa çıkma konusunda ve öğrencilere başarılı bir şekilde rehberlik etme konusunda kendilerine güvenmeden teknolojiyi kullanmaktadır (Alagic ve Palenz, 2006). Erdemir, Bakırcı ve Eyduran (2009) öğretmenlerin teknoloji kullanımı konusunda yeterli düzeyde öz güvene sahip olmayışlarının öğrencilik dönemlerinde aldıkları eğitim öğretimle ilişkilendirdikleri ifade etmiştir. Benzer şekilde Sancar Tokmak vd (2013) öğrencilik dönemine vurgu yaparak öğretmen adaylarının TPAB'leri ile ilgili öz-güvenlerini ölçmek, etkili teknoloji entegrasyonunu sağlamada önemli bir adım olacağını belirtmişlerdir. Bu görüşler doğrultusunda bu çalışmada matematik öğretmen adaylarının ТPAB güven algılarının belirlenmesi önemli görülmüştür.

Öğretmen adaylarının sadece TPAB algı düzeylerinin belirlenmesi yeterli olmayıp algılarına etki eden faktörlerin belirlenmesi gerekmektedir (Albion, 1999, 2000). Bu doğrultuda literatür incelendiğinde öğretmen adaylarının TPAB düzeylerini farklı değişkenler açısından ele alan çalışmaların olduğu görülmektedir. Bu çalışmalarda ele alınan değişkenlerinden biri cinsiyettir. Koh ve Sing (2011) cinsiyetin TPAB algısını etkileyebilecek bir faktör olduğunu ifade etmiştir. Ancak yapılan araştırmalar içerisinde sonuçları birbirleriyle çelişen çalışmalar bulunmaktadır. Çalışmaların çoğunluğu cinsiyet değişkeninin öğretmenlerin/öğretmen adaylarının TPAB düzeyleri üzerinde anlamlı bir farklılık yaratmadığını göstermektedir (Akgün, 2013; Gömleksiz ve Fidan, 2011; Kaya vd., 2010; Kaya vd., 2011; Kazu ve Erten, 2011; Koh ve Sing, 2011; Mutlu ve Erdoğan, 2012; Sancar-Tokmak vd., 2013). Buna karşın bu sonuçla çelişen araştırma bulguları da mevcuttur (Erdoğan ve Şahin, 2010; Koh, Chai ve Tsai, 2010; Tsai, 2008). Yapılan çalışma sonuçları arasında elde edilen farklılıklar bilgisayar sahibi olma değişkeninin etkisini araştıran çalışma sonuçların- 
da da görülmektedir (Mutluoğlu ve Erdoğan, 2012; Yavuz Konakman vd, 2013). Yapılan çalışmalarda ele alınan bir diğer değişken sınıf düzeyidir. TPAB ile ilgili yapılan çalışmaların çoğunun son sınıflarda öğrenim gören öğretmen adaylarıyla gerçekleştirildiği görülmektedir (Erdoğan ve Ader, 2013; Kaya vd., 2010; Kaya vd, 2011, Yavuz Konokman vd. ,2013). Bu durum araştırmacıların öğretmen adaylarının derslerin çoğunu almış olmalarını tercih etmelerinden kaynaklanabilir. Ancak öğretmen eğitimi açısından bakıldığında farklı sınıf düzeylerindeki öğretmen adaylarının TPAB düzeylerinin belirlenmesinin aldıkları eğitimin etkisinin belirlenmesi açısından önemli olduğu düşünülmektedir. Yapılan bazı çalışmalarda sınıf düzeyi açısından anlamlı bir farklılık belirlenmezken (Kazu ve Erten, 2011) bazı çalışmalarda TPAB'ın farklı bileşenleri için anlamlı farklılıklar belirlenmiştir (Kaya vd, 2010; Sancar-Tokmak vd., 2013). Bilgisayar kullanım sıklığ1nın teknoloji kullanımına ilişkin algı üzerinde anlamlı farklılık yarattığına dair sonuçlar olmasına karşın (Baki, Kutluca ve Birgin, 2008; Demiralay ve Karadeniz, 2010) TPAB bileşenleri açısından bu değişkenin etkisinin araştırıldığ bu değişkenin TPAB bileşenlerinde anlamlı bir farklılık yaratıp yaratmadığının belirlenmesinin literatüre katkı sağlayacağı düşünülmektedir. Öz yeterlik kuramını ortaya koyan Bandura (1977) kişilerin becerilerini etkin şekilde kullanabilmeleri için önce kendilerini o alanda güvenli hissetmeleri gerektiğini savunmaktadır. Bu nedenle öğretmen adaylarının teknoloji öz yeterlik algılarının güven algıları üzerinde farklılık yaratıp yaratmadığının incelenmesinin gerekli olduğu düşünülmektedir. Literatürdeki farklı sonuçlara açıklık kazandırmak, mevcut çalışma sonuçlarını desteklemek ve yeni sonuçlar ortaya koymak amacıyla bu çalışmada ilköğretim matematik öğretmen adaylarının TPAB güven algılarının cinsiyet, bilgisayar sahibi olma, sınıf düzeyi, bilgisayar kullanım sıklığı, teknoloji kullanma düzeyi değişkenleri açısından incelemek amaçlanmıştır.

\section{Yöntem}

$\mathrm{Bu}$ araştırmada matematik öğretmen adaylarının TPAB'e yönelik güven düzeylerinin belirlenmesi amacıyla nicel araştırma desenlerinden betimsel tarama (survey) modeli kullanılmıştır. Bunun yanı sıra, ТРАВ güven düzeylerinin cinsiyet, sınıf düzeyi, bilgisayar 
sahibi olma durumu, bilgisayar kullanım sıklığı ve teknoloji kullanma düzeyi değişkenlerine göre karşılaştırılması amaçlandığından ilişkisel tarama modellerinden nedensel-karşılaştırma yaklaşımı kullanılmıştır.

\section{Çalışma Grubu}

Araştırmanın çalışma grubunu, Güneydoğu Anadolu Bölgesi ve Doğu Anadolu Bölgesi'nde bulunan orta büyüklükte iki üniversitenin İlköğretim Matematik Öğretmenliği Programı tüm sınıf düzeylerinde öğrenim toplam 527 kişi oluşturmuştur. Çalışmanın başında öğretmen adaylarına araştırmanın kapsamı anlatılmış ve araştırmaya gönüllü olan öğretmen adaylarıyla çalışılmıştır. Veriler kat1lımcılardan 2012-2013 akademik y1l bahar döneminde toplanmıştır. Öğretmen adaylarının cinsiyetlerine ve sınıf düzeylerine göre dağılımları Tablo1'de sunulmuştur.

Tablo 1. Araştırmaya Katılan Öğretmen Adaylarının Özellikleri

\begin{tabular}{|c|c|c|c|c|c|c|c|}
\hline & \multicolumn{7}{|c|}{ Üniversitenin bulunduğu bölge } \\
\hline Üniversite & \multicolumn{3}{|c|}{$\begin{array}{l}\text { Güneydoğu Anadolu Böl- } \\
\text { gesi }\end{array}$} & \multicolumn{4}{|c|}{ Doğu Anadolu Bölgesi } \\
\hline Cinsiyet & Bayan & Erkek & $\begin{array}{l}\text { Kayıp } \\
\text { Veri }\end{array}$ & Bayan & Erkek & $\begin{array}{l}\text { Kayıp } \\
\text { Veri }\end{array}$ & $\begin{array}{l}\text { Top- } \\
\text { lam }\end{array}$ \\
\hline \multicolumn{8}{|l|}{ Sinıf Düzeyi } \\
\hline 1. Sinıf & 33 & 15 & 1 & 64 & 13 & & 125 \\
\hline 2. Sinıf & 32 & 15 & & 66 & 21 & 1 & 134 \\
\hline 3. $\quad$ Sinıf & 21 & 22 & & 58 & 21 & & 122 \\
\hline 4. SinIf & 16 & 12 & & 64 & 48 & & 140 \\
\hline Diğer & - & - & & 1 & 3 & & 4 \\
\hline Toplam & 102 & 64 & 1 & 253 & 106 & 1 & 527 \\
\hline
\end{tabular}

\section{Veri Toplama Araçları}

$\mathrm{Bu}$ çalışmada öğretmen adaylarının TPAB güven düzeylerini belirlemek amacıyla orijinali Graham vd. (2009) tarafindan geliştirilen ve Timur ve Taşar (2011) tarafından Türkçeye uyarlanan Teknolojik Pedagojik Alan Bilgisi Güven ölçeği kullanılmıştır. Graham vd. (2009) tarafından geliştirilen ölçek fen bilgisi öğretmenlerin TPAB güven düzeylerini belirlemeyi amaçlayan 31 maddelik bir ölçme aracıdır. Ölçek Teknolojik Pedagojik Alan Bilgisi (TPAB), Teknolojik Pedagojik Bilgi (TPB), Teknolojik Alan Bilgisi (TAB) ve Teknolojik 
Bilgi (TB) olmak üzere 4 boyuttan meydana gelmektedir. Orijinal ölçek 1 = Hiç güvenmiyorum, 2= Az güveniyorum, 3= Orta derece güveniyorum, 4= Çokça güveniyorum $5=$ Oldukça Güveniyorum 6= Tamamen güveniyorum, $0=\mathrm{Bu}$ türden teknolojileri bilmiyorum (sadece TB boyutundaki maddelerde) şeklinde $6^{\text {ee }} 1$ Likert tipte olup 50 fen bilgisi öğretmenine uygulanmıştır. Ölçekte negatif madde bulunmamaktadır. Araştırmacılar örneklem sayısının yeterli olmamasını gerekçe göstererek yapı geçerliliğini incelememişlerdir. Graham vd (2009) tarafından ölçeğin alt boyutları için Cronbach Alpha iç tutarlılık katsayıları TPAB için $\alpha=.951$; TPB için $\alpha=.913$; TAB için $\alpha=.971$ ve TB için $\alpha=.922$ olarak hesaplamışlardır (Graham vd., 2009).

Ölçeği Türkçe'ye uyarlayan Timur ve Taşar (2011) 5'li bir derecelendirme kullanarak orijinal ölçekte "Çokça güveniyorum” ve "Oldukça güveniyorum" ifadelerinin birbirine çok yakın olması nedeniyle kısmen güveniyorum ifadesini çıkararak yalnızca "Çokça güveniyorum" ifadesini kullanmışlardır. Çevirisi yapılan ölçeği 393 fen ve teknoloji öğretmenine uygulayan araştırmacılar doğrulayıcı faktör analizi yoluyla 4 alt faktörden oluşan ölçeğin faktör yapısının Türk kültüründe de korunduğu belirlemişlerdir $(\chi 2 / \mathrm{df}=2.86, p=.000$, $\mathrm{NFI}=.87$, RMSEA=.069) Uyarlanan ölçeğin Cronbach Alpha güvenirlik katsayısı ölçeğin tümü için $\alpha=.92$; TPAB boyutu için $\alpha=.89$,TPB boyutu için $\alpha=.87$, TAB boyutu için $\alpha=.89$ ve TB boyutu için $\alpha=.86$ olarak hesaplanmıştır (Timur ve Taşar, 2011).

\section{Teknolojik Pedagojik Alan Bilgisi Güven Ölçeği'nin Geçerlik ve Güvenirlik Çalışması}

TPAB güven ölçeği fen ve teknoloji dersiyle ilgili olup fen öğretmenlerine uygulanarak geliştirilmiştir. $\mathrm{Bu}$ çalışmada uzman görüşleri doğrultusunda söz konusu ölçeğin araştırmamızın amaçlarına uygun olduğu belirlenmiş ve matematik dersine uyarlanmasına karar verilmiştir. Ölçekte yer alan "Fen" kelimesi yerine "Matematik"; "Bilimsel olayları" kelimesi yerine "Matematiksel" kelimesi kullanılmıştır. Ayrıca 16-20. Maddelerde yer alan "Bilim insanlarına" ifadesi çıkarılmıştır. 6'lı Likert yapı kullanılan ölçekte yanıt kategorileri $0=$ Hiç güvenmiyorum, $1=\mathrm{Az}$ güveniyorum, 2= Orta derece güveniyorum, 3= Çokça güveniyorum 4= Oldukça Güveniyorum 5= Tamamen güveniyorum olarak düzenlenmiştir. 
Matematik öğretmen adaylarından elde edilen veri setinin ölçeğin orijinalindeki 4 boyutlu yapıyı sağlayıp sağlamadığını belirlemek amacıyla doğrulayıcı faktör analizi yapılmıştır. Faktör analizine başlamadan önce elde edilen verilerin analiz için uygun olup olmadiğ 1 belirlenmiş ve uç değerlere sahip 51 satır (kişi) çıkarılarak 476 kişiye ait veri seti üzerinden işleme devam edilmiştir. Elde edilen KMO değeri 0-1 arasında değişmekte olup bu değer için, .5-.7 arası orta, .7.8 iyi, .8-.9 arası büyük, .9 üzeri mükemmel olarak değerlendirilmektedir (Field, 2005). Örneklem büyüklüğünün yeterliliğini belirlemek amaciyla yapılan test sonucu $(\mathrm{KMO}=.935)$ ve Barlett Küresellik testi sonuçlar1 $\left(X^{2}=8136.049\right.$; sd=465; $\left.\mathrm{p}=.000\right)$ dikkate alındığında örneklem sayısı yeterli bulunmuştur. Anti-image korelasyon matrisinde köşegende yer alan değerlerin .868-.975 arasında değişmesi madde bazında örneklem sayısının yeterli olduğunu göstermektedir (Field, 2005; Sipahi vd., 2010).

4 boyutlu yapının veri setine uyumunun sağlanıp sağlanmadığını belirlemek amacıyla doğrulayıcı faktör analizi uygulanmıştır (Çokluk, Şekercioğlu ve Büyüköztürk, 2010: 218). Yapılan analiz sonucunda $\chi 2 / \mathrm{df}=4.07, \mathrm{p}=.000, \mathrm{RMSEA}=.08, \quad \mathrm{NFI}=.82$, $\mathrm{GFI}=.81$ olarak hesaplanmıştır.

Kikare değerine ilişkin $p$ değerinin manidar olmaması $(p=.00)$ olması diğer kriterleri incelememiz gerektiğine işaret etmektedir (Çokluk vd., 2010). Uyum iyiliği değerleri için ilgili alan yazında GFI $>$ 0.95, RMSEA<.06, NFI>.95 kabul edilir değerler olarak ifade edilmiştir (Hu ve Bentler, 1999; Newsom, 2012; Tabachnick ve Fidell, 2007). Bu değerler ölçüt alındığında 4 faktörlü yapıdan elde edilen değerler modelin doğrulanmadığı göstermektedir. Bu aşamada programın sunduğu modifikasyon önerileri incelenerek modelin iyileştirilmesi yoluna gidilmiştir. 21-22. ve 24-25. maddeler arasında yapılan modifikasyon sonucu elde edilen uyum iyiliği değerleri $\chi 2 / \mathrm{df}=3.21, \mathrm{p}=.000, \mathrm{RMSEA}=.068, \mathrm{NFI}=.85, \mathrm{GFI}=.84$ şeklindedir. Değerler incelendiğinde yapılan iyileştirmeye rağmen modelin doğrulanmadığg görülmektedir.

Yapılan doğrulayıcı faktör analiziyle veri setinin ölçeğin orijinalindeki yapıyı sağlamadığının belirlenmesinin ardından açımlayıcı faktör analizi kapsamında kullanılan uygun yöntemlerden biri olan temel bileşenler analizi ile faktör yapısı incelenmiştir (Mahmoud ve Kamel, 2010). Varimax dik döndürme yönteminin kullanıldığı ana- 
lizde faktör yükü alt kesme noktası .40 olarak alınmıştır (Gable, 1986; Hatcher, 1994). Ayrıca iki faktörde alınabilecek yük miktarı arasındaki farkın en az 0.10 olması gerektiği varsayılmıştır (Menard, 2002). Yapılan incelemeler sonucu ölçeğin orijinalinde yer alan 8.,15. maddeler iki faktörde yakın yük değerleri aldığı için ve 25 . madde ise bir faktörde iki madde yer almasından dolayı ölçekten çıkarılmıştır. Sonuçta 5 faktörlü bir yapı elde edilmiştir.

Tablo 2. TPAB Ölçeğinin Temel Bileșenler Analizi Sonuçları

\begin{tabular}{|c|c|c|c|c|c|c|c|}
\hline Madde & $\begin{array}{l}\text { Ortak } \\
\text { faktör } \\
\text { var- } \\
\text { yansı }\end{array}$ & $\begin{array}{l}\text { 1. Fak- } \\
\text { tör için } \\
\text { yük } \\
\text { değerle } \\
\text { ri }\end{array}$ & $\begin{array}{l}\text { 2. Fak- } \\
\text { tör için } \\
\text { yük } \\
\text { değerle } \\
\text { ri }\end{array}$ & $\begin{array}{l}\text { 3. Fak- } \\
\text { tör için } \\
\text { yük } \\
\text { değerle } \\
\text { ri }\end{array}$ & $\begin{array}{l}\text { 4. Fak- } \\
\text { tör için } \\
\text { yük } \\
\text { değerle } \\
\text { ri }\end{array}$ & $\begin{array}{l}\text { 5. Fak- } \\
\text { tör için } \\
\text { yük } \\
\text { değerle } \\
\text { ri }\end{array}$ & $\begin{array}{l}\text { Madde } \\
\text { Toplam } \\
\text { Korela- } \\
\text { syonu }\end{array}$ \\
\hline 3 & ,660 & ,759 & & & & & 691 \\
\hline 4 & 679 & ,751 & & & & & ,704 \\
\hline 5 & 651 & ,720 & & & & & ,700 \\
\hline 6 & ,599 & ,658 & & & & & ,672 \\
\hline 7 & ,583 & 619 & & & & & ,645 \\
\hline 2 & 450 & ,588 & & & & & ,562 \\
\hline 1 & ,481 & ,583 & & & & & ,553 \\
\hline 30 & ,657 & & ,768 & & & & ,667 \\
\hline 29 & ,656 & & ,761 & & & & ,704 \\
\hline 27 & 679 & & ,746 & & & & ,732 \\
\hline 26 & ,627 & & ,730 & & & & ,680 \\
\hline 31 & ,603 & & ,717 & & & & ,661 \\
\hline 28 & ,608 & & ,665 & & & & 652 \\
\hline 20 & ,722 & & & 823 & & & ,741 \\
\hline 17 & ,748 & & & ,820 & & & ,781 \\
\hline 19 & ,700 & & & ,791 & & & ,736 \\
\hline 18 & ,725 & & & ,788 & & & ,754 \\
\hline 16 & ,621 & & & ,716 & & & 682 \\
\hline 10 & 631 & & & & ,725 & & ,631 \\
\hline 12 & ,681 & & & & ,710 & & ,725 \\
\hline 14 & ,637 & & & & 677 & & 694 \\
\hline 11 & ,603 & & & & 653 & & 669 \\
\hline 9 & ,604 & & & & ,571 & & ,673 \\
\hline 13 & ,539 & & & & ,524 & & ,628 \\
\hline 22 & ,745 & & & & & ,829 & ,669 \\
\hline 21 & ,657 & & & & & ,768 & ,593 \\
\hline 23 & ,610 & & & & & 691 & ,576 \\
\hline 24 & ,420 & & & & & ,508 & ,460 \\
\hline
\end{tabular}


K.Açıkgül,R.Aslaner / EÜ Eğitim Fakültesi Dergisi, 17(1) (2015), 118-152

\begin{tabular}{llllll}
\hline Özdeğer & 10,351 & 2,726 & 1,927 & 1,389 & 1,183 \\
$\begin{array}{l}\text { Açıklanan Varyans } \\
\text { Oranı }\end{array}$ & 14,622 & 13,721 & 13,368 & 11,913 & 9,148 \\
$\begin{array}{l}\text { Toplam=\%62,772 } \\
\text { Croanbach alpha }\end{array}$ &, 869 &, 876 &, 894 &, 870 &, 769 \\
\hline
\end{tabular}

Tablo incelendiğinde 1, 3 ve 4. faktörlerde yer alan maddelerin ölçeğin orijinalindeki yapılarla uyumlu olduğu görülmektedir. 1. Faktörde yer alan maddeler (1-7. maddeler) TPAB boyutu, 3. faktörde yer alan maddeler (16-20. maddeler) TAB boyutu, 4. Boyutta yer alan maddeler (9-14. maddeler) TPB boyutu olarak ele alınmıştır. Bu çalışama da ölçeğin orijinalinden farklı olarak TB boyutu altında yer alan maddeler 2 boyut altında (Tablo 5 'de 2 . ve 5 . boyut) faktörleşmiştir. $\mathrm{Bu}$ boyutlar incelendiğinde 2. faktör altında yer alan maddelerin (26-31. Maddeler) ileri düzey teknoloji bilgisine işaret ederken 5. Faktör altında yer alan maddelerin (21-24. Madde) temel teknoloji bilgisini içerdiği belirlenmiştir. Bu bağlamda 2. Faktör İleri teknoloji Bilgisi (İTB), 5. faktör Temel Teknoloji Bilgisi (TTB) olarak adlandırılmıştır.

Ayrıca öğretmen adaylarının cinsiyet, sınıf düzeyi, bilgisayar sahibi olma, bilgisayar kullanım sıklığı, teknoloji kullanım düzeyi değişkenine ilişkin bilgiler araştırmacılar tarafından hazırlanan Kişisel bilgi formu aracılığıyla toplanmıştır.

\section{Verilerin Analizi}

Verilerin analizinde, TPAB güven ölçeğinde bulunan 5 boyuta ait puanların aritmetik ortalamaları ve standart sapmaları hesaplanmıştır. Cinsiyet, bilgisayara sahibi olma, sınıf düzeyi, bilgisayar kullanma sıklı̆̆1, teknoloji kullanma düzeyi durumlarına göre ögretmen adaylarının TPAB puanları arasında anlamlı bir fark olup olmadığını belirlemek amacıyla F testi yapılmıştır. Yapılan Bonferroni düzeltmesi sonucu çıkarımsal analizlerde anlamlılık düzeyi $\alpha=0,01$ olarak belirlenmiştir (Abdi, 2010). Ayrıca elde edilen sonuçların pratikteki anlamlılığını ortaya çıkarmak için etki büyüklükleri hesaplanmıştır (Özsoy ve Özsoy, 2013). Yapılan F testi sonuçları için Cohen $\mathrm{f}$ değerleri hesaplanmıştır. Elde edilen etki büyüklükleri Cohen $\mathrm{f}$ için $\mathrm{f}=.10$ "küçük", $\mathrm{f}=.25$ "orta", $\mathrm{f}=.40$ "büyük" etki büyüklüğü olarak yorumlanmıştır (Cohen, 1988). 
Araştırmaya katılan öğretmen adaylarının TPAB ve alt bilgi alanlarına ilişkin puanların karşılaştırmalı olarak yorumlanabilmesi amacıyla her ölçeğin toplam puanları madde sayılarına bölünerek 6'lı derecelendirme puanlarına dönüştürülmüştür. Bu puan ortalamalarının yorumlanmasında aşağıdaki puan aralıkları ve karşılık gelen güven düzeyleri kullanılmıştır.

Tablo 3. TPAB Yeterlik Puanların Yorumlanması Amaciyla Kullanılan Puan Aralıkları

\begin{tabular}{ll}
\hline Puan aralığ $\mathbf{~}$ & Güven Düzeyi \\
\hline $0-0.85$ & Hiç güvenmiyorum. \\
$0.86-1.68$ & Az güveniyorum. \\
$1.69-2.51$ & Orta düzeyde güveniyorum. \\
$2.52-3.34$ & Çokça güveniyorum. \\
$3.35-4.17$ & Oldukça güveniyorum. \\
$4.18-5.00$ & Tamamen güveniyorum. \\
\hline
\end{tabular}

\section{Bulgular}

\section{Öğretmen Adaylarının TPAB Güven Algıları}

Matematik öğretmen adaylarının teknolojik pedagojik alan bilgisi güven düzeylerine yönelik bulgular Tablo 4'te verilmiştir.

Tablo 4. Öğretmen Adaylarının TPAB Güven Düzeylerinin Dağılımı $(\mathrm{n}=476)$

\begin{tabular}{cccc}
\hline Alt ölçek & $\overline{\mathbf{X}}$ & $\mathbf{S}$ & Güven düzeyi \\
\hline TPABGÖ & 3,36 &, 68 & Oldukça güveniyorum. \\
TPAB & 3,31 &, 73 & Çokça güveniyorum \\
TPB & 3,40 &, 82 & Oldukça güveniyorum. \\
TAB & 3,27 & 1,00 & Çokça güveniyorum \\
TTB & 3,68 &, 91 & Oldukça güveniyorum. \\
ITB & 3,18 & 1,06 & Çokça güveniyorum \\
\hline
\end{tabular}

Yapılan betimsel analiz sonuçları öğretmen adaylarının TPAB güven düzeyleri genel ortalama puanlarının $\bar{X}=3,36$ olduğu görülmektedir. Buna bağlı olarak, ölçeğin geneli için adayların pu- 
anlarının ortalaması "Oldukça güveniyorum." düzeyinde bulunmaktadır. Alt boyutlarda ise, puanların ortalama 3.18 ile 3.68 arasında değiştiği belirlenmiştir. Alt boyutlardan alınan puanlarının ortalaması TPAB, TAB, İTB boyutu için "Çokça güveniyorum." TPB ve TTB boyutu için "Oldukça güveniyorum.” Aralığına karşılık gelmektedir.

Cinsiyet Değişkenine Göre Öğretmen Adaylarının TPAB Güven Algilart

Öğretmen adaylarının teknolojik pedagojik alan bilgisi yeterlik düzeylerinin cinsiyet değişkenine göre anlamlı düzeyde farklılaşıp farklılaşmadığına ilişkin bulgular Tablo 6'da verilmiştir.

Tablo 5. Öğretmen Adaylarının TPAB Puanlarının Cinsiyet Değişkenine Göre Betimsel Analiz Sonuçları

\begin{tabular}{|c|c|c|c|c|c|c|c|c|c|c|c|c|}
\hline \multirow[b]{2}{*}{ Cinsiyet } & \multirow[b]{2}{*}{$\mathbf{N}$} & \multicolumn{2}{|c|}{ TPABGÖ } & \multicolumn{2}{|c|}{ TPAB } & \multicolumn{2}{|c|}{ TPB } & \multicolumn{2}{|c|}{ TAB } & TTB & \multicolumn{2}{|c|}{ İTB } \\
\hline & & $\bar{x}$ & $\mathbf{S}$ & $\bar{x}$ & $\mathbf{S}$ & $\bar{x}$ & $\mathbf{S}$ & $\bar{x}$ & $\mathbf{S}$ & $\mathbf{S}$ & $\bar{x}$ & $\mathbf{S}$ \\
\hline Kadın & 32 & 13,32 & ,70 & 3,32 & ,73 & 3,38 & ,82 & 3,21 & 1,02 & 3,68,92 & 3,06 & 1,09 \\
\hline Erkek & 15 & 43,44 & ,63 & 3,31 & ,73 & 3,46 & ,81 & 3,40 & ,94 & 3,68, 88 & 3,42 & 99 \\
\hline Toplam & 47 & 53,36 & ,68 & 3,31 & ,73 & 3,40 & ,82 & 3,27 & 1,00 & 3,68,91 & 3,18 & 1,06 \\
\hline
\end{tabular}

Tablo 6. Öğretmen Adaylarının TPAB Puanlarının Cinsiyetine Göre F-Testi Analizi Sonuçları

\begin{tabular}{|c|c|c|c|c|c|c|c|c|}
\hline Boyut & $\begin{array}{l}\text { Varyansın } \\
\text { kaynağı }\end{array}$ & $\begin{array}{l}\text { Kareler } \\
\text { Top. }\end{array}$ & Sd & $\begin{array}{l}\text { Karele } \\
\text { r Ort. }\end{array}$ & F & $\mathbf{P}$ & $\begin{array}{l}\text { Co- } \\
\text { hen } \\
\text { f }\end{array}$ & Güç \\
\hline \multirow{3}{*}{ TPABGÖ } & $\begin{array}{l}\text { Gru- } \\
\text { plararas1 }\end{array}$ & 1,51 & 1 & 1,51 & 3,27 & ,071 & & \\
\hline & Gruplariçi & 218,18 & 473 & ,46 & & & & \\
\hline & Toplam & 219,69 & 474 & & & & & \\
\hline \multirow{2}{*}{ ТРAB } & $\begin{array}{l}\text { Gru- } \\
\text { plararas1 }\end{array}$ & ,02 & 1 & ,02 & ,03 & ,868 & & \\
\hline & Gruplariçi & 251,82 & 473 & ,532 & & & & \\
\hline \multirow{3}{*}{ TPB } & $\begin{array}{l}\text { Gru- } \\
\text { plararas1 }\end{array}$ & ,70 & 1 & ,700 & 1,04 & ,307 & & \\
\hline & Gruplariçi & 317,12 & 473 & 61 & & & & \\
\hline & Toplam & 317,82 & 474 & & & & & \\
\hline
\end{tabular}


K.Açıkgül,R.Aslaner / Ë̈ Eğitim Fakültesi Dergisi, 17(1) (2015), 118-152

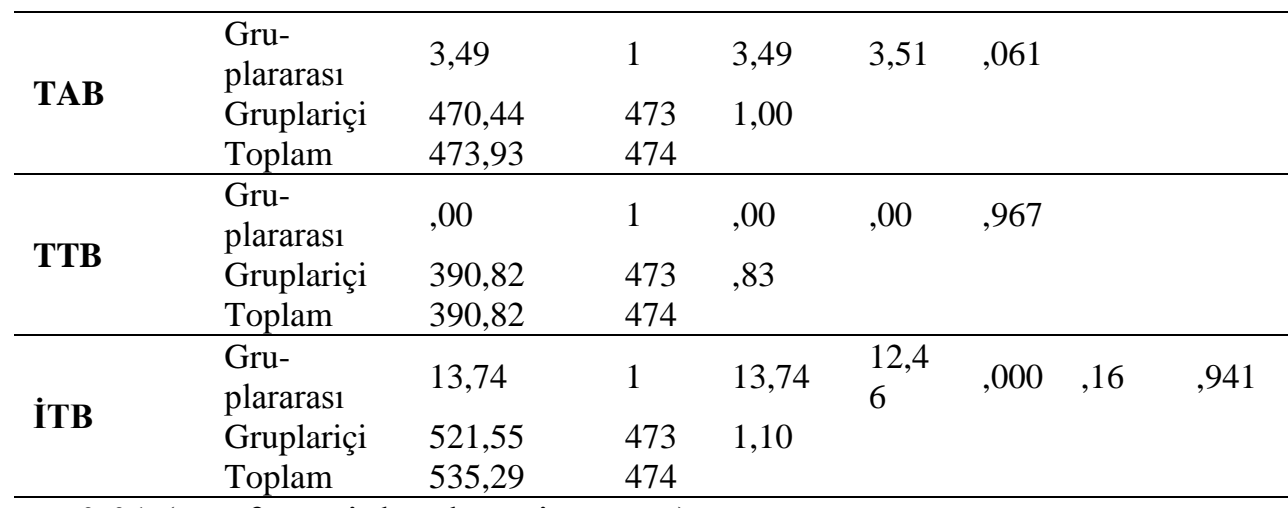

$\mathrm{p}<0,01$ (Bonferroni düzeltmesi sonras1)

Tablo'daki veriler incelendiğinde, öğretmen adaylarının ölçeğin tamamı ve alt boyutlardan aldıkları puanların İTB boyutu hariç cinsiyet değişkenine göre istatistiksel olarak anlamlı düzeyde farklılaşmadığı görülmektedir. Öğretmen adaylarının İTB güven puanları cinsiyetlerine göre istatistiksel olarak anlamlı düzeyde farklılaşmaktadır $[\mathrm{F}(1,473)=12,463, \mathrm{p}<.01]$. Bu fark için hesaplanan etki büyüklüğü değerleri (Cohen $\mathrm{f}=.16$ ) cinsiyetin adayların İTB boyutundaki güven düzeyleri üzerinde küçük etkiye sahip olduğu söylenebilir.

\section{Sınıf Düzeyi Değişkenine Göre Öğretmen Adaylarının TPAB Güven Düzeyleri}

Öğretmen adaylarının teknolojik pedagojik alan bilgisi güven düzeylerinin sınıf düzeyi değişkenine göre betimsel istatistikleri Tablo 7 'de ve puanlar arasında anlamlı düzeyde farklılaşma olup olmadığına ilişkin f testi sonuçları Tablo 8'te verilmiştir.

Tablo 7. Öğretmen Adaylarinin TPAB Güven Puanlarının Sınıf Düzeyi Değişkenine Göre Betimsel Analiz Sonuçları

\begin{tabular}{|c|c|c|c|c|c|c|c|c|c|c|c|c|c|}
\hline & & $\mathbf{T P}$ & ABGÖ & TPA & & TPB & & TAF & & TTE & & İTB & \\
\hline $\begin{array}{l}\text { Sinıf } \\
\text { Düzeyi }\end{array}$ & $\mathbf{N}$ & $\bar{x}$ & S & $\bar{x}$ & S & $\bar{x}$ & S & $\bar{x}$ & S & $\bar{x}$ & S & $\bar{x}$ & S \\
\hline 1. Sinıf & 110 & 3,23 & ,76 & 3,31 & ,77 & 3,23 & ,88 & 3,18 & ,99 & 3,44 & ,91 & 2,96 & 1,19 \\
\hline 2. Sinıf & 121 & 3,33 & 61 & 3,22 & ,66 & 3,31 & ,77 & 3,22 & 1,06 & 3,69 & ,88 & 3,23 & 96 \\
\hline 3. Sinıf & 111 & 3,40 & , 72 & 3,32 & ,74 & 3,51 & ,80 & 3,27 & 1,07 & 3,75 & 94 & 3,24 & 1,10 \\
\hline
\end{tabular}


K.Açıkgül,R.Aslaner / Ë̈ Eğitim Fakültesi Dergisi, 17(1) (2015), 118-152

$\begin{array}{llllllllllllll}\text { 4. Sınıf } & 130 & 3,48,63 & 3,40 & , 75 & 3,55 & , 79 & 3,41 & , 89 & 3,83,88 & 3,28 & 1,00 \\ \text { Diğer } & 4 & 3,21,52 & , 316 & , 25 & 3,13 & , 92 & 3,20 & , 63 & 3,50 & 1,02 & 2,92 & , 99 \\ \text { Toplam } & 476 & 3,36,68 & 3,31 & , 73 & 3,40 & , 82 & 3,24 & 1,00 & 3,68,91 & 3,18 & 1,06\end{array}$

Tablo 8. Öğretmen Adaylarının TPAB Puanlarının Sınıff Düzeyi

Değişkenine Göre F Testi Analiz Sonuçları

\begin{tabular}{|c|c|c|c|c|c|c|}
\hline Boyut & $\begin{array}{l}\text { Varyansın } \\
\text { kaynağı }\end{array}$ & $\begin{array}{l}\text { Kareler } \\
\text { Top. }\end{array}$ & Sd & $\begin{array}{l}\text { Kareler } \\
\text { Ort. }\end{array}$ & $\mathbf{F}$ & $\mathbf{P}$ \\
\hline \multirow{3}{*}{ TPABGÖ } & Gruplararası & 4,37 & 4 & 1,09 & 2,38 & 051 \\
\hline & Gruplariçi & 215,73 & 471 & ,46 & & \\
\hline & Toplam & 220,10 & 475 & & & \\
\hline \multirow{3}{*}{ ТPAB } & Gruplararası & 2,028 & 4 & ,52 & ,95 & ,432 \\
\hline & Gruplariçi & 250,28 & 471 &, 53 & & \\
\hline & Toplam & 252,31 & 475 & & & \\
\hline \multirow{3}{*}{ TPB } & Gruplararası & 8,70 & 4 & 2,18 & 3,31 & 011 \\
\hline & Gruplariçi & 309,13 & 471 & 67 & & \\
\hline & Toplam & 317,83 & 475 & & & \\
\hline \multirow{3}{*}{ TAB } & Gruplararası & 3,71 & 4 & ,927 & ,93 & ,448 \\
\hline & Gruplariçi & 470,75 & 471 & 1,00 & & \\
\hline & Toplam & 474,46 & 475 & & & \\
\hline \multirow{3}{*}{ TTB } & Gruplararas1 & 9,78 & 4 & 2,45 & 3,02 & ,018 \\
\hline & Gruplariçi & 381,36 & 471 & ,81 & & \\
\hline & Toplam & 391,14 & 475 & & & \\
\hline \multirow{3}{*}{ İTB } & Gruplararası & 7,79 & & 1,95 & 1,73 & ,142 \\
\hline & Gruplariçi & 529,72 & & 1,13 & & \\
\hline & Toplam & 537,51 & & & & \\
\hline
\end{tabular}

${ }^{*} \mathrm{p}<0.01$ (Bonferroni düzeltmesi sonrast)

Tablo'daki veriler incelendiğinde, öğretmen adaylarının TPABGÖ ve alt boyutlardan aldıkları sınıf düzeyi değişkenine göre istatistiksel olarak anlamlı düzeyde farklılaşmadığı görülmektedir. Katılımcıların aritmetik ortalamaları dikkate alındığında, farklı sınıf düzeyinde bulunan öğretmen adaylarının güven düzeylerinde farklılıklar olduğu söylenebilir.

Bilgisayar Sahibi Olma Değişkenine Göre Öğretmen Adaylarının Güven Düzeyleri 
Bilgisayar sahibi olma değişkeni açısından öğretmen adaylarının güven düzeylerine ilişkin betimsel istatistikler Tablo'da ve anlamlı biçimde farklılaşıp farklılaşmadığını belirlemek amacıyla yapılan f testi sonuçları Tablo 10'te verilmiştir.

Tablo 9. Öğretmen Adaylarinin TPAB Puanlarının Bilgisayar Sahibi Olma Değişkenine Göre Betimsel Analiz Sonuçları

\begin{tabular}{|c|c|c|c|c|c|c|c|c|c|c|c|c|c|}
\hline \multirow[b]{2}{*}{ Bilgisayar } & & \multicolumn{2}{|c|}{ TPABGÖ } & \multicolumn{2}{|c|}{ ТРАВ } & \multicolumn{2}{|l|}{ TPB } & \multicolumn{2}{|c|}{ TAB } & \multicolumn{2}{|l|}{ TTB } & \multicolumn{2}{|l|}{ ITB } \\
\hline & & $\bar{x}$ & S & $\bar{x}$ & $\mathbf{S}$ & $\bar{x}$ & $\mathbf{S}$ & $\bar{x}$ & $\mathbf{S}$ & $\bar{x}$ & S & $\bar{x}$ & S \\
\hline Hayır & 121 & 3,1 & 64 & 3,14 & ,69 & 3,14 & ,74 & 3,13 & 1,09 & 3,56 & ,90 & 2,93 & 1,00 \\
\hline Evet & 353 & & 68 & 3,38 & ,73 & 3,50 & 8 & 23,3 & 2 97 & 3,72 & ,91 & 3,26 & 1,07 \\
\hline Toplam & 474 & & 36,68 & 3,32 & ,73 & 3,40 & , 8. & 23,2 & 81,00 & 03,68 & ,91 & 3,18 & 1,06 \\
\hline
\end{tabular}

Tablo 10. Öğretmen Adaylarının TPAB Puanlarının Bilgisayar Sahibi Olma Değişkenine Göre F Testi Analiz Sonuçları

\begin{tabular}{|c|c|c|c|c|c|c|c|c|}
\hline Boyut & $\begin{array}{l}\text { Varyansın } \\
\text { kaynağı }\end{array}$ & $\begin{array}{l}\text { Kareler } \\
\text { Top. }\end{array}$ & Sd & $\begin{array}{l}\text { Kareler } \\
\text { Ort. }\end{array}$ & $\mathbf{F}$ & $\mathbf{P}$ & $\begin{array}{l}\text { Cohen } \\
\text { f }\end{array}$ & Güç \\
\hline \multirow{3}{*}{ TPABGÖ } & Gruplararası & 6,412 & 1 & 6,412 & 14,165 & ,000* & ,17 & ,964 \\
\hline & Gruplariçi & 253,672 & 472 & ,453 & & & & \\
\hline & Toplam & 220,085 & 473 & & & & & \\
\hline \multirow{3}{*}{ TPAB } & Gruplararası & 5,410 & 1 & 5,410 & 10,454 & ,001* & ,15 & ,897 \\
\hline & Gruplariçi & 244,267 & 472 & ,518 & & & & \\
\hline & Toplam & 249,677 & 473 & & & & & \\
\hline \multirow{3}{*}{ TPB } & Gruplararası & 11,461 & 1 & 11,461 & 17,754 & ,000* & ,19 & 988 \\
\hline & Gruplariçi & 304,686 & 472 & ,646 & & & & \\
\hline & Toplam & 316,146 & 473 & & & & & \\
\hline \multirow{3}{*}{ TAB } & Gruplararası & 3,279 & 1 & 3,279 & 3,291 & ,070 & & \\
\hline & Gruplariçi & 470,312 & 472 & ,996 & & & & \\
\hline & Toplam & 473,591 & 473 & & & & & \\
\hline \multirow{3}{*}{ TTB } & Gruplararası & 2,474 & 1 & 2,474 & 3,006 & ,084 & & \\
\hline & Gruplariçi & 388,495 & 472 & ,823 & & & & \\
\hline & Toplam & 390,939 & 473 & & & & & \\
\hline \multirow{3}{*}{ İTB } & Gruplararası & 10,012 & 1 & 10,012 & 8,978 & ,003* & ,14 & ,849 \\
\hline & Gruplariçi & 526,387 & 472 & 1,115 & & & & \\
\hline & Toplam & 536,400 & 473 & & & & & \\
\hline
\end{tabular}


Tablo'deki veriler incelendiğinde, öğretmen adaylarının ölçeğin geneli TPABGÖ $[\mathrm{F}(1,472)=14,165]$ ve TPAB $[\mathrm{F}(1,472)=10,454, \mathrm{p}<.01], \quad$ TPB $[\mathrm{F}(1,472)=17,754, \quad \mathrm{p}<.01] ;$ ІंТВ $[\mathrm{F}(1,472)=8,978, \mathrm{p}<.01]$ boyutları için algıladıkları güven düzeylerinin bilgisayar sahibi olma durumu değişkene göre istatistiksel olarak anlamlı düzeyde farklılaştığı görülmektedir. TAB ve TTB boyutları açısından anlamlı bir farklılık yoktur. Hesaplanan Cohen $\mathrm{f}$ değerleri incelendiğinde bilgisayar sahibi olma durumunun ölçeğin genelinde ve TPAB, TPB, İTB boyutlarında küçük etkiye sahip olduğu söylenebilir.

\section{Bilgisayar Kullanım Sıklı̆̆ Değişkenine Göre Ö̆̆retmen Adaylarının TPAB Güven Düzeyleri}

Tablo 11. Öğretmen Adaylarının TPAB Puanlarının Bilgisayar Kullanma S1klığı Değişkenine Göre Betimsel Analiz Sonuçları

\begin{tabular}{|c|c|c|c|c|c|c|c|c|c|c|}
\hline & & TPABGÖ & TPA & & TPB & & TAB & TTB & İTB & \\
\hline Siklık & $\mathbf{N}$ & $\bar{x} \quad S$ & $\bar{x}$ & S & $\bar{x}$ & S & $\bar{x}$ & $\bar{x}$ & $\bar{x}$ & S \\
\hline $\begin{array}{l}\text { 1.Hiç } \\
\text { kullanmıyor } \\
\text { um }\end{array}$ & 14 & 3,05,73 & 3,04 & ,79 & 3,23 & ,82 & $2,821,28$ & $3,27,83$ & 2,86 & 1,04 \\
\hline $\begin{array}{l}\text { 2. Ayda } \\
\text { birkaç saat }\end{array}$ & 37 & 3,29,66 & 3,23 & ,75 & 3,33 & ,68 & $3,59,75$ & $3,54,79$ & 2,83 & 1,25 \\
\hline $\begin{array}{l}\text { 3. Haf } \\
\text { birkas }\end{array}$ & 97 & 3,22,56 & 3,18 & ,68 & 3,24 & ,76 & $3,201,00$ & $3,51,84$ & 2,94 & 1,04 \\
\hline $\begin{array}{l}\text { 4. Haftada } \\
\text { birkaç gün }\end{array}$ & 94 & 3,31,72 & 3,23 & ,75 & 3,37 & ,85 & $3,151,05$ & 3,70,95 & 3,18 & 1,05 \\
\hline $\begin{array}{l}\text { 5. Günde } \\
\text { birkaç saat }\end{array}$ & 152 & $3,47,67$ & 3,47 & ,72 & 3,50 & ,81 & $3,281,00$ & 3,79,94 & 3,34 & 1,00 \\
\hline $\begin{array}{l}\text { 6. Gün içer- } \\
\text { isinde sü- } \\
\text { rekli }\end{array}$ & 42 & 3,69, 65 & 3,57 & ,68 & 3,82 & ,77 & $3,55,85$ & 3,84,93 & 3,69 & ,936 \\
\hline Toplam & 436 & 3,37, 68 & 3,33 & ,73 & 3,42 & 81 & $3,271,00$ & $3,68,91$ & 3,19 & 1,06 \\
\hline
\end{tabular}

Tablo 12: Öğretmen Adaylarinin TPAB Puanlarının Bilgisayar Kullanma Sıklığı Değişkenine Göre Anova Analiz Sonuçları 
K.Açıkgül,R.Aslaner / EÜ Eğitim Fakültesi Dergisi, 17(1) (2015), 118-152

\begin{tabular}{|c|c|c|c|c|c|c|c|c|c|}
\hline Boyut & $\begin{array}{l}\text { Varyansın } \\
\text { kaynağı }\end{array}$ & $\begin{array}{l}\text { Kareler } \\
\text { Top. }\end{array}$ & Sd & $\begin{array}{l}\text { Kareler } \\
\text { Ort. }\end{array}$ & $\mathbf{F}$ & $\mathbf{P}$ & $\begin{array}{l}\text { Fark (Bon- } \\
\text { ferroni) }\end{array}$ & $\begin{array}{l}\text { Cohen } \\
\text { f }\end{array}$ & Güç \\
\hline \multirow{3}{*}{ TPABGÖ } & Gruplararası & 10,104 & 5 & 2,021 & 4,600 & ,000* & $6>3,6>1$ & ,23 & ,974 \\
\hline & Gruplariçi & 188,917 & 430 & ,439 & & & & & \\
\hline & Toplam & 199,021 & 435 & & & & & & \\
\hline \multirow{3}{*}{ ТPAB } & Gruplararası & 10,109 & 5 & 2,022 & 3,931 & ,002* & $6>3$ & 21 & ,946 \\
\hline & Gruplariçi & 221,142 & 430 & ,514 & & & & & \\
\hline & Toplam & 231,250 & 435 & & & & & & \\
\hline \multirow{3}{*}{ ТPB } & Gruplararası & 12,004 & 5 & 2,401 & 3,784 & ,002* & $6>3$ & ,21 & 937 \\
\hline & Gruplariçi & 272,823 & 430 & ,634 & & & & & \\
\hline & Toplam & 284,827 & 435 & & & & & & \\
\hline \multirow{3}{*}{ ТАВ } & Gruplararası & 11,512 & 5 & 2,302 & 2,355 & ,040 & & & \\
\hline & Gruplariçi & 420,482 & 430 & ,978 & & & & & \\
\hline & Toplam & 431,994 & 435 & & & & & & \\
\hline \multirow{3}{*}{ TTB } & Gruplararası & 8,940 & 5 & 1,788 & 2,193 & ,054 & & & \\
\hline & Gruplariçi & 350,646 & 430 & ,815 & & & & & \\
\hline & Toplam & 359,586 & 435 & & & & & & \\
\hline \multirow{3}{*}{ İTB } & Gruplararası & 26,054 & 5 & 5,211 & 4,843 & ,000* & $6>2,6>3$ & ,24 & ,980 \\
\hline & Gruplariçi & 462,654 & 430 & 1,076 & & & & & \\
\hline & Toplam & 488,708 & 435 & & & & & & \\
\hline
\end{tabular}

Tablo'daki veriler incelendiğinde, öğretmen adaylarının ölçeğin tamamından aldıkları puanların bilgisayar kullanım sıklığı değişkenine göre istatistiksel olarak anlamlı düzeyde farklılaştığ1 görülmektedir [F $(5,430)=4,600, \mathrm{p}<.01]$. Bu fark için hesaplanan etki büyüklüğü değeri (Cohen $\mathrm{f}=.23$ ) küçük etkiye işaret ederken orta düzey bir etkiye yakın olduğu söylenebilir. Farkın hangi gruplardan kaynaklandığını bulmak amacıyla yapılan Bonferroni testi sonucunda, bilgisayarı gün içinde sürekli kullandığını ifade eden öğretmen adaylarının TPABGÖ güven puanlarının haftada birkaç saat kullandığını söyleyen öğretmen adaylarının puanlarından ve hiç kullanmadığını ifade eden ögretmen adaylarının puanlarından anlamlı düzeyde daha yüksek olduğu bulunmuştur.

Öğretmen adaylarının TPAB puanları bilgisayar kullanım sıklığına göre istatistiksel olarak anlamlı düzeyde farklılaşmaktadır [F $(5,430)=3,931, p<.01]$. Bu fark için hesaplanan etki büyüklügünün (Cohen $\mathrm{f}=.21$ ) küçük bir etkiye işaret etmektedir. Farkın hangi gruplardan kaynaklandığını bulmak amacıyla yapılan Bonferroni testi 
sonucunda, bilgisayarı gün içinde sürekli kullandığını ifade eden öğretmen adaylarının TPAB puanlarının haftada birkaç saat kullandığını söyleyen öğretmen adaylarının puanlarından anlamlı düzeyde daha yüksek olduğu bulunmuştur.

Öğretmen adaylarının TPB güven puanları bilgisayar kullanım sıklığına göre istatistiksel olarak anlamlı düzeyde farklılaşmaktadır $[\mathrm{F}(5,430)=3,784 \mathrm{p}<.01]$. Bu fark için hesaplanan etki büyüklügünün (Cohen $\mathrm{f}=.21)$ küçük bir etkiye işaret etmektedir. Farkın hangi gruplardan kaynaklandığını bulmak amacıyla yapılan Bonferroni testi sonucunda, bilgisayarı gün içinde sürekli kullandığını ifade eden öğretmen adaylarının TPB güven puanlarının haftada birkaç saat kullandığını söyleyen öğretmen adaylarının puanlarından anlamlı düzeyde daha yüksek olduğu bulunmuştur.

Öğretmen adaylarının İTB güven puanları bilgisayar kullanım sıklığına göre istatistiksel olarak anlamlı düzeyde farklılaşmaktadır $[\mathrm{F}(5,408)=4,518 \mathrm{p}<.008]$. Bu fark için hesaplanan etki büyüklügünün (Cohen $\mathrm{f}=.24)$ küçük bir etkiye işaret ederken orta düzey bir etkiye yakın olduğu söylenebilir. Farkın hangi gruplardan kaynaklandığını bulmak amacıyla yapılan Bonferroni testi sonucunda, bilgisayarı gün içinde sürekli kullandığını ifade eden öğretmen adaylarının İTB güven puanlarının haftada birkaç saat ve ayda birkaç saat kullandığını söyleyen öğretmen adaylarının puanlarından anlamlı düzeyde daha yüksek olduğu bulunmuştur.

\section{Teknoloji Kullanma Düzeyi Değişkenine Göre Öğretmen Adaylarının TPAB Güven Düzeyleri}

Tablo 13. Öğretmen Adaylarının TPAB Puanlarının Teknoloji Kullanma Düzeyi Değişkenine Göre Betimsel Analiz Sonuçları

\begin{tabular}{|c|c|c|c|c|c|c|c|c|c|c|c|c|c|}
\hline & & TPAI & 3GÖ & TPAB & & TPB & & TAB & & TTB & & İTB & \\
\hline $\begin{array}{l}\text { Teknoloji } \\
\text { Kullanma } \\
\text { düzeyi }\end{array}$ & $\mathrm{N}$ & $\bar{x}$ & S & $\bar{x}$ & S & $\bar{x}$ & S & $\bar{x}$ & S & $\bar{x}$ & S & $\bar{x}$ & $S$ \\
\hline 1.Yetersiz & 43 & 3,04 & ,65 & 3,09 & 63 & 3,02 & ,79 & 3,08 & 1,02 & 3,48 & 90 & 2,56 & 1,20 \\
\hline $\begin{array}{l}\text { 2. Kısmen } \\
\text { Yeterli }\end{array}$ & 279 & 3,22 & ,62 & 3,18 &, 70 & 3,26 & ,78 & 3,14 & 1,01 & 3,53 & ,90 & 2,99 & 1,00 \\
\hline 3 Yeterli & 151 & 3,70 & ,64 & 3,62 & ,71 & 3,74 & ,78 & 3,55 & 91 & 4,00 & ,83 & 3,67 & ,92 \\
\hline
\end{tabular}


K.Açıkgül,R.Aslaner / EÜ Eğitim Fakültesi Dergisi, 17(1) (2015), 118-152

\begin{tabular}{llllllllllllll}
\hline Toplam & 473 & 3,36 & 68 & 3,31 &, 73 & 3,39 & ,815 & 3,27 & 1,00 & 3,68 & 91 & 3,17 & 1,06 \\
\hline
\end{tabular}

Tablo 14. Öğretmen Adaylarının TPAB Puanlarının Teknoloji Kullanma Düzeyi Değiş̧enine Göre F Testi Analiz Sonuçları

\begin{tabular}{|c|c|c|c|c|c|c|c|c|c|}
\hline Boyut & $\begin{array}{l}\text { Varyansın } \\
\text { kaynağı }\end{array}$ & $\begin{array}{l}\text { Kareler } \\
\text { Top. }\end{array}$ & Sd & $\begin{array}{l}\text { Kareler } \\
\text { Ort. }\end{array}$ & $\mathbf{F}$ & $\mathbf{P}$ & $\begin{array}{l}\text { Fark (Bon- } \\
\text { ferroni) }\end{array}$ & $\begin{array}{l}\text { Cohen } \\
\text { f }\end{array}$ & Güç \\
\hline \multirow{3}{*}{ TPABGÖ } & Gruplararası & 28,20 & 2 & 14,10 & 35,37 & ,000* & $3>2,3>1$ & ,39 & ,999 \\
\hline & Gruplariçi & 187,37 & 470 & ,40 & & & & & \\
\hline & Toplam & 215,58 & 472 & & & & & & \\
\hline \multirow{3}{*}{ ТРAB } & Gruplararas1 & 21,24 & 2 & 10,62 & 21,96 & ,000* & $3>2,3>1$ & 31 & 999 \\
\hline & Gruplariçi & 227,26 & 470 & ,48 & & & & & \\
\hline & Toplam & 248,50 & 472 & & & & & & \\
\hline \multirow{3}{*}{ TPB } & Gruplararası & 29,36 & 2 & 14,68 & 24,28 & ,000* & $3>2,3>1$ & ,32 & ,999 \\
\hline & Gruplariçi & 284,10 & 470 & ,60 & & & & & \\
\hline & Toplam & 313,46 & 472 & & & & & & \\
\hline \multirow{3}{*}{ TAB } & Gruplararas1 & 17,46 & 2 & 8,73 & 9,08 &, $000^{*}$ & $3>2$ & 20 & ,975 \\
\hline & Gruplariçi & 451,64 & 470 & ,96 & & & & & \\
\hline & Toplam & 469,09 & 472 & & & & & & \\
\hline \multirow{3}{*}{ ТTВ } & Gruplararas1 & 24,19 & 2 & 12,09 & 15,65 & ,000* & $3>2,3>1$ & ,26 & ,999 \\
\hline & Gruplariçi & 363,14 & 470 &, 77 & & & & & \\
\hline & Toplam & 387,32 & 472 & & & & & & \\
\hline \multirow{3}{*}{ İTB } & Gruplararas1 & 61,90 & 2 & 30,95 & 31,20 & ,000* & $3>2,3>1$ & ,36 & ,999 \\
\hline & Gruplariçi & 466,18 & 470 & 99 & & & & & \\
\hline & Toplam & 528,08 & 472 & & & & & & \\
\hline
\end{tabular}

Tablo'daki veriler incelendiğinde, ölçeğin tamamından alınan puanların öğretmen adaylarının teknoloji kullanma düzeyleri açısından istatistiksel olarak anlamlı düzeyde farklılaştığ görülmektedir $[\mathrm{F}(2,470)=35,372, \mathrm{p}<.01]$. Hesaplanan etki büyüklüğü değeri (Cohen $\mathrm{f}=.39$ ) teknoloji kullanma düzeyi değişkeninin güven puanları üzerinde büyük bir etkiye sahip olduğu söylenebilir. Farkın hangi gruplardan kaynaklandığını bulmak amacıyla yapılan Bonferroni testi sonucunda, teknoloji kullanma konusunda kendisini yeterli bulan öğretmen adaylarının, kısmen yeterli ve yetersiz bulan öğretmen adaylarının puanlarından anlamlı düzeyde daha yüksek olduğu bulunmuştur. 
Öğretmen adaylarının TPAB güven puanları teknoloji kullanım düzeyi değişkenine göre istatistiksel olarak anlamlı düzeyde farklılaşmaktadır [F $(2,470)=21,960, \mathrm{p}<.01]$. Bu fark için hesaplanan etki büyüklügü (Cohen $\mathrm{f}=.31$ ) orta düzey olduğu görülmüştür. Farkın hangi gruplardan kaynaklandığını bulmak amacıyla yapılan Bonferroni testi sonucunda, teknoloji kullanma konusunda kendisini yeterli bulan ögretmen adaylarının puanları, kısmen yeterli ve yetersiz bulan öğretmen adaylarının puanlarından anlamlı düzeyde daha yüksek olduğu bulunmuştur.

Öğretmen adaylarının TPB güven puanları teknoloji kullanım düzeyi değişkenine göre istatistiksel olarak anlamlı düzeyde farklılaşmaktadır [F $(2,470)=24,282, \mathrm{p}<.01]$. Bu fark için hesaplanan etki büyüklüğü (Cohen $\mathrm{f}=.32$ ) orta düzey bir etkiye işaret etmektedir. Farkın hangi gruplardan kaynaklandığını bulmak amacıyla yapılan Bonferroni testi sonucunda, teknoloji kullanma konusunda kendisini yeterli bulan öğretmen adaylarının puanları kısmen yeterli ve yetersiz bulan öğretmen adaylarının puanlarından anlamlı düzeyde daha yüksek olduğu bulunmuştur.

Öğretmen adaylarının TAB güven puanları teknoloji kullanım düzeyi değişkenine göre istatistiksel olarak anlamlı düzeyde farklılaşmaktadır [F $(2,470=9,083, \mathrm{p}<.01]$. Bu fark için hesaplanan etki büyüklügü (Cohen $\mathrm{f}=.20)$ ) küçük bir etkiye işaret etmektedir. Farkın hangi gruplardan kaynaklandığını bulmak amacıyla yapılan Bonferroni testi sonucunda, teknoloji kullanma konusunda kendisini yeterli bulan öğretmen adaylarının puanları, kısmen yeterli bulan öğretmen adaylarının puanlarından anlamlı düzeyde daha yüksek olduğu bulunmuştur.

Öğretmen adaylarının TTB güven puanları teknoloji kullanım düzeyi değişkenine göre istatistiksel olarak anlamlı düzeyde farklılaşmaktadır $[\mathrm{F}(2,470)=15,653, \mathrm{p}<.01]$. Bu fark için hesaplanan etki büyüklüğü $($ Cohen $\mathrm{f}=.26)$ ) orta düzeydir. Farkın hangi gruplardan kaynaklandığını bulmak amacıyla yapılan Bonferroni testi sonucunda, teknoloji kullanma konusunda kendisini yeterli bulan öğretmen adaylarının puanları, kısmen yeterli ve yetersiz bulan öğretmen adaylarının puanlarından anlamlı düzeyde daha yüksek olduğu bulunmuştur.

Öğretmen adaylarının İTB güven puanları teknoloji kullanım düzeyi değişkenine göre istatistiksel olarak anlamlı düzeyde 
farklılaşmaktadır [F $(2,470)=31,204, \quad \mathrm{p}<.01]$. Bu fark için hesaplanan etki büyüklüğü (Cohen $\mathrm{f}=.39)$ ) orta bir etkiye işaret ederken büyük bir etkiye yakın olduğu söylenebilir. Farkın hangi gruplardan kaynaklandığını bulmak amacıyla yapılan Bonferroni testi sonucunda, teknoloji kullanma konusunda kendisini yeterli bulan öğretmen adaylarının puanları, kısmen yeterli ve yetersiz bulan öğretmen adaylarının puanlarından anlamlı düzeyde daha yüksek olduğu bulunmuştur.

\section{Sonuç ve Tartışma}

$\mathrm{Bu}$ çalışma ilköğretim matematik öğretmen adaylarının TPAB güven düzeylerinin belirlenmesi ve bu düzeylerin çeşitli değişkenler açısından farklılaşma durumunun incelenmesi amacıyla yapılmıştır. Araştırmada ölçeğin geneli için öğretmen adaylarının kendilerine "Oldukça" güvendikleri sonucuna ulaşılmıştır. Alt boyutlara gelindiğinde ise adayların sırasıyla TPAB, TAB, İTB boyutlarında kendilerine "Çokça" güvenirken TTB ve TPB boyutlarında "Oldukça" güvendikleri belirlenmiştir. Tüm boyutlar ele alındığında öğretmen adaylarının kendilerine en çok güvendikleri boyut Temel Teknoloji Bilgisi (TTB) boyutuyken en az güvendikleri boyut İleri Teknoloji Bilgisi (ITB) boyutudur. Bu bulgudan hareketle öğretmen adaylarının başta pedagojik ve temel teknolojik bilgiyi içeren alanlar olmak üzere bütün alanlarda kendilerine yeterli düzeyde güvendikleri söylenebilir. Öğretmen adaylarının en güvensiz hissettikleri alanda dahi kendilerine "Çokça" güvenmeleri ve ölçeğin geneli için kendilerine "Oldukça" güvenmeleri adayların TPAB konusunda kendilerine yeterli düzeyde güvendikleri şeklinde yorumlanabilir. Akgün (2013)'ün öğretmenlerin derslerinde teknolojiyi kullanabilmeleri için kendilerine güvenmelerinin gerekli olduğu şeklindeki görüşü dikkate alındığında elde edilen sonuç olumlu olarak yorumlanabilir. İlgili araştırmalar incelendiğinde araştırmanın genel sonuçlarına paralel olarak farklı bölümlerde okuyan öğretmen adaylarının teknopedagojik alan bilgileri konusunda kendilerini yeterli gördükleri ve kendilerine güvendikleri ortaya çıkmıştır (Gömleksiz ve Fidan, 2011; Kaya vd, 2011; Sancar Tokmak vd., 2013; Yavuz Konokman vd., 2013). Baki vd. (2008) tarafindan yapılan öğretmen adaylarının bilgisayar destekli eğitime yönelik öz yeterlik algılarının incelendiği çalışma sonuçları matematik ögretmen 
adaylarının bilgisayar destekli eğitim konusunda kendilerine güvendiklerini göstermiştir. Erdemir vd. (2009) eğitim-öğretimde teknolojiyi kullanabilme ve öğretim amaçlı teknolojik materyal hazırlayabilme konusunda farklı bölümlerde okuyan öğretmen adaylarının öz güven düzeylerine ilişkin görüşlerinin hangi seviyede olduğunu belirlemeyi amaçlamışlardır. Adayların basit ve günlük kullanılan teknolojiyi kullanabilme bilgi ve becerisi konusunda öz güvenlerinin yeterli olduğu ancak bilgisayarı eğitim amaçlı istenen düzeyde kullanma becerisine sahip olmadıkları sonucuna ulaşmışlardır. Teknoloji entegrasyonuna ilişkin öğretmen yetiştirmede yaşanan çeşitli sorunlara rağmen öğretmen adayların kendilerine güvenmeleri umut verici bir durum olarak ele alınabilir.

Araştırmada bayan ve erkek öğretmen adaylarının TPAB güven düzeylerinin İTB boyutu hariç istatistiksel olarak anlamlı düzeyde farklılaşmadığı belirlenmiştir. Bu sonuçlar literatürde farklı bölümlerdeki öğretmen adaylarının genel TPAB algılarının cinsiyet değişkenine göre farklılaşıp farklılaşmadığını ele alan çalışma sonuçlarıyla örtüşmektedir (Akgün, 2013; Gömleksiz ve Fidan, 2011; Kaya vd., 2010; Kaya vd., 2011; Kazu ve Erten, 2011; Koh ve Sing, 2011; Sancar-Tokmak vd., 2013). Ayrıca matematik öğretmen adaylarının bilgisayar destekli eğitime yönelik öz yeterlik algılarının incelendiği çalışmada Baki ve ark. (2008) de cinsiyete göre bir farklılaşmaya rastlanmamıştır. Mutluoğlu ve Erdoğan (2012) matematik öğretmenleriyle yürüttükleri çalışmalarında katılımcıların cinsiyetleri ile TPAB bileşenlerindeki düzeyleri arasında anlamlı bir farklılığın olmadığını belirlemişlerdir. Benzer şekilde Jang ve Tsai (2012) Tayvan'daki matematik öğretmenleriyle gerçekleştirdikleri çalışmalarında cinsiyet değişkeni açısından anlamlı bir farklılık belirleyememişlerdir. Ancak bu sonuçlar Erdoğan ve Şahin'in (2010) matematik öğretmen adaylarıyla gerçekleştirdikleri ve erkek öğretmen adaylarının TPAB düzeylerinin kızlardan anlamlı düzeyde farklılaştı̆̆ını belirdikleri çalışma sonuçlarıyla çelişmektedir. Bunu yanı sıra bu çalışmada İTB boyutunda erkeklerin lehine anlamlı bir farklılık çıkmıştır. Benzer şekilde, Akkoyunlu ve Orhan'ın (2003) çalışmalarında, Bilgisayar ve Öğretim Teknolojileri Bölümü'nde öğrenim gören öğretmen adaylarının temel bilgisayar kullanma becerileri açısından cinsiyete göre bir farklılık yokken üst düzey beceriler için erkekler lehine anlamlı farklılığın olduğu görülmüştür. Araştır- 
macılar bu durumu kız öğrencilerin bilgisayar ile ilgili üst düzey becerilerde kendilerine daha az güveniyor olmalarından kaynaklanabileceğini ifade etmişlerdir. Ayrıca, Koh, Chai ve Tsai, (2010) çalışmalarında TB boyutunda erkek ve kız öğretmen adayları arasında erkekler lehine anlamlı bir farklılık olduğunu belirlemişlerdir.

Araştırmanın sonuçlarından biride öğretmen adaylarının sınıf düzeylerine göre TPAB güven puanlarında anlamlı bir farklılık elde edilmemesidir. Elde ettiğimiz bu sonuç literatürde yer alan bazı çalışma sonuçlarını desteklemektedir. Nitekim, Kazu ve Erten (2011) yaptıkları çalışmada sınıf öğretmeni adaylarının Web Pedagojik İçerik Bilgisine ilişkin görüşlerinin sınıf düzeyine göre anlamlı farklılık göstermediği sonucuna ulaşmışlardır. Sancar-Tokmak vd., (2013), çalışmalarında öğretmen adaylarının sınıf düzeylerine göre yalnızca TB boyutunda farklılaştığını diğer boyutlarda farklılaşmadığını belirlemiştir. Araştırmacılar bu durumu öğretmen adaylarına verilen eğitim sırasında öğretmen adaylarının TB konusunda güvenlerinin yükselmesinin sağlandığı ancak TPAB konusunda güvenlerinin yükselmesinin sağlanamadığı şeklinde ifade etmiş̧lerdir. Ayrıca literatürde bu sonuçlarla çelişen araştırmalar bulguları da bulunmaktadır. Kaya vd (2010) sınıf öğretmeni adaylarının TPAB açısından özgüvenlerini belirlemeyi amaçladıkları çalışmalarında 4. sınıfta öğrenim gören öğretmen adaylarının sahip oldukları TPAB öz-güven seviyelerinin, 3. sınıfta öğrenim gören öğretmen adaylarından anlamlı olarak daha yüksek olduğunu saptamışlardır. Baki vd. (2008) 4. sınıfta öğrenim gören öğretmen adayları ile 2.sınıfta öğrenim gören öğretmen adaylarının BDE'ye ilişkin öz yeterlik algı puanları arasında 4.sınıfta bulunan öğretmen adayları lehine anlamlı bir fark olduğu tespit edilmiştir.

Öğretmen adaylarının sınıf düzeylerine göre ortalamaları incelendiğinde genel olarak 1. Sınıftan 4. Sınıfa doğru bir artış meydana geldiği belirlenmiştir. Yavuz Konokman ve ark. (2013) son sınıf öğretmen adaylarıyla yaptığı çalışmasında öğretmen adaylarının TPAB'a ilişkin yeterlilik algılarının yüksek olmasını eğitimlerinin son döneminde olmaları ile teknoloji, pedagoji ve alan derslerinin çoğunu almış olmalarıyla açıklamıştır. Benzer şekilde bizim çalışmamızdan elde edilen sonuç öğretmen adaylarının aldıkları derslerin güven düzeyleri üzerindeki olumlu yansıması olarak ele alınabilir. 
Diğer taraftan bu çalışmada bilgisayar sahibi olma durumu açısından öğretmen adayları TAB ve TTB boyutlarında istatistiksel olarak anlamlı bir farklılaşma göstermezken ölçeğin geneli ve diğer alt boyutlar için istatistiksel olarak anlamlı düzeyde bir farklılaşma olduğu sonucuna ulaşılmıştır. Ortalamalar bu farklılaşmanın bilgisayar sahibi olanların lehine olduğunu göstermektedir. Temel teknolojik bilgi konusuna ilişkin güven düzeyinde farklılık olmaması çalışmanın öğretim yılı sonunda yapılması ve tüm sınıf düzeylerindeki öğretmen adaylarının Temel Bilgisayar dersini almış olmalarıyla açıklanabilir. Baki vd (2008) matematik öğretmen adaylarının BDE'e ilişkin özyeterlik algılarının bilgisayara sahip olma durumuna göre değişmediğini göstermiştir. Yavuz Konokman ve ark. (2013) teknolojiye erişim düzeyi yüksek olan öğretmen adaylarının TPAB düzeylerinin daha yüksek olduğunu saptamıştır. Mutluoğlu ve Erdoğan (2012) çalışmalarında, bilgisayar sahibi olan ilköğretim matematik öğretmenlerinin bilgisayar sahibi olmayan öğretmenlere göre tüm bilgi düzeylerinin daha yüksek olduğunu; ancak TPAB'in her bileşeninde bu farklılığın anlamlı olmadığını ifade etmişlerdir.

Çalışmada öğretmen adaylarının TPAB güven düzeyleri bilgisayar kullanım sıklığı değişkenine açısından incelenmiştir. Yapılan analiz sonucu ölçeğin genelinde ve TPAB, TPB, İTB boyutlarında öğretmen adayları arasında anlamlı bir farklılık olduğu tespit edilmiştir. Ortalamalar incelendiğinde bilgisayarı gün içerisinde sürekli kullanan öğretmen adaylarının kendilerine daha fazla güvenmeleri önemli bir bulgu olarak değerlendirilebilir. Baki ve arkadaşları (2008) matematik öğretmen adaylarının bilgisayarı kullanma sıklığı artıkça BDE'ye yönelik öz yeterlikleri algı puanlarının arttığını tespit ederek ögretmen adayları arasında bilgisayarı daha sık kullananlar lehine anlamlı bir fark olduğu sonucuna ulaşmışlardır. Demiralay ve Karadeniz'in (2010) çalışmalarında elde ettikleri bulgular bilgisayarı sürekli kullanan öğretmen adaylarıyla bilgisayarı sık sık ve ara sıra kullanan öğretmen adaylarının teknoloji kullanım düzeyleriyle ilgili öz yeterlilik algılarında anlamlı düzeyde farklılık olduğunu göstermiştir.

$\mathrm{Bu}$ çalışmada öğretmen adaylarının TPAB güven düzeylerinin teknoloji kullanma düzeyi değişkenine göre anlamlı düzeyde farklılaştığı görülmüştür. Teknoloji kullanma düzeyi değişkeni öğretmen adaylarının teknoloji konusundaki öz yeterlilik algıları olarak ele 
alınmıştır. Bu bağlamda kendilerini farklı yeterlilik düzeyinde gören öğretmen adaylarının güven düzeylerinin farklılaşmasının ve ortalamaların yetersizden yeterliye doğru artış göstermesinin yeterlilik ve güven algısı arasındaki pozitif ilişkiye işaret ettiği söylenebilir.

\section{Öneriler}

Öğretmen adaylarının TPAB konusunda kendilerine oldukça güvenmeleri gelecekte matematik eğitiminde teknoloji tabanlı yaklaşımların öğrenme ve öğretme süreçlerinde yoğun olarak kullanılacağı ihtimalini gündeme getirebilir. $\mathrm{Bu}$ duruma ek olarak öğretmen adaylarının temel teknolojik bilgi konusunda kendilerine oldukça güvenmeleri onların matematik eğitiminde teknolojiyi kullanabilecek temel yeterlilikleri sahip olduğunu gösterebilir. Ancak bu çalışmada ele alınan teknoloji yeterlilikler genel teknolojik bilgileri içermekte olup matematik eğitiminde kullanılan teknolojiler ile ilgili bilgiler içermemektedir. Uygun teknoloji seçimi ve kullanımı önemli ögretmen yeterliliklerinden biridir. Bu nedenle öğretmen adaylarına matematik ögretiminde kullanılan yazılımlar hakkında eğitim vermek, bu programları kullanabilecekleri ortamlar sağlamak onların matematik eğitiminde teknoloji kullanımına ilişkin algılarında farkındalık ve değişiklik meydana getirebilir.

Matematik eğitiminde teknoloji çeşitli amaçlarla kullanılabilir. Bunlar sunum amaçlı kullanılmaktan bir dersin tamamına teknoloji entegre etmeye kadar gidebilir. $\mathrm{Bu}$ çalışmada sadece öğretmen adaylarının TPAB güven düzeyleri belirlenmiş olup derslerinde teknolojiyi hangi amaçlarla ve nasıl kullanmayı düşündükleri incelenmemiştir. $\mathrm{Bu}$ nedenle farklı TPAB güven düzeyindeki öğretmen adaylarının teknolojiyi derslerine nasıl entegre etmeyi düşündükleri araştırılabilir. Archambault ve Crippen (2009) öğretmenlerin TPAB yeterlilik düzeylerini belirlemek için yaptıkları çalışmalarında katılımcıların pedagoji, içerik ve pedagojik içerik bilgilerinin üst düzey olmasına karşın, bu bilgilere teknolojik bilginin eklenmesi durumunda kendilerine daha az güvendikleri sonucu elde etmişlerdir. $\mathrm{Bu}$ çalışma, TPAB çerçevesinde bulunan bileşenlerden 4 tanesi ile sınırlı olup pedagoji, alan ve pedagojik alan bilgisine yer verilmemiştir. $\mathrm{Bu}$ bağlamda öğretmen adaylarının bu çalışma da ele alınan bileşenlerdeki güven düzeyleri üzerinde teknolojinin etkisinin 
belirlenmesi amacıyla uygun veri toplama araçları geliştirilerek öğretmen adaylarının alan bilgisi, pedagoji bilgisi ve pedagojik alan bilgisi incelenebilir. TPAB öğretmenlerin öğretim uygulamalarına teknolojiyi etkili bir şekilde entegre edebilmeleri için ne bilmesi gerektiğini ele alan bir çerçevedir (Schmidd vd, 2009). Her ne kadar bu çalışmada önemli bulgular elde edilse de, ölçek ile toplanan veriler, bilgiden ziyade öğretmen adaylarının TPAB güven algısı yansıttığ varsayılmıştır. $\mathrm{Bu}$ durum, öğretmen adaylarının gerçek TPAB düzeylerini belirlemeyi engellemiştir. Gelecek çalışmalarda bu hususlara dikkat edilerek uygun veri toplama araçlarının kullanılması önerilmektedir .

\section{Kaynaklar}

Abbitt, J. T. (2011). An investigation of the relationship between self-efficacy $\quad b$ liefs about technology integration and technological pedagogical content knowledge (TPACK)among preservice teachers. Journal of Digital Learning in Teacher Education, 27(4), 134-143.

Abdi, H. (2010). Holm's sequential bonferroni procedure. In N. Salkind (Ed.), E cyclopedia of research design (pp. 1-8). Thousand Oaks, CA: Sage.

Agyei, D. D. \& Voogt, J. (2011a). ICT use in the teaching of mathematics: Implications for Professional development of pre-service teachers in Ghana. Education and Information Technologies, 16(4), 423-439.

Agyei, D. D. \& Voogt, J. (2011b). Exploring the potential of the will, skill, tool model in Ghana: Predicting prospective and practicing teachers' use of technology. Computers \& Education, 56(1), 91-100.

Agyei, D. and Voogt, J. (2012). Developing Technological Pedagogical Content Knowledge in preservice mathematics teachers through teacher design teams. Australasian journal of educational technology, 28 (4).

Akgün, F. (2013). Öğretmen adaylarının web pedagojik içerik bilgileri ve öğretmen öz yeterlik algıları ile ilişkisi. Trakya Üniversitesi Eğitim Fakültesi Dergisi, 3(1), 48 -58.

Akkoyunlu, B. ve Orhan, F. (2003). Bilgisayar ve öğretim teknolojileri eğitimi (BÖTE) bölümü öğrencilerinin bilgisayar kullanma öz-yeterlik inancı ile demografik özellikleri arasındaki ilişki. The Turkish Online Journal of Educational Tecnology-TOJET, 2(3), 86-93.

Alagic, M., \& Palenz, D. (2006). Teachers explore linear and exponential growth: Spreadsheets as cognitive tools. Journal of Technology and Teacher Education,14(3), 633-649.

Albion, P.R. (1999). Self-efficacy beliefs as an indicator of teachers' preparedness for teaching with technology. In J. Price et al. (Eds.), Proceedings of $S$ 
K.Açıkgül,R.Aslaner / Ë̈ Eğitim Fakültesi Dergisi, 17(1) (2015), 118-152

ciety for Information Technology \& Teacher Education International Conference 1999 (pp.1602-1608). Chesapeake, VA: AACE.

Albion, P. R. (2000). Interactive multimedia problem-based learning for enhancing preservice teachers' selfefficacy beliefs about teaching with computers: Design, development and evaluation. Unpublished $\mathrm{PhD}$, University of Southern Queensland, Toowoomba.

Archambault, L., and Crippen, K. (2009). Examining TPACK among K-12 online distance educators in the United States Contemporary Issues in Technology and Teacher Education, 9(1), 71-88.

Archambault, L. M., \& Barnett, J. H. (2010). Revisiting technological pedagogical content knowledge: Exploring the TPCK framework. Computers \& Education, 55(4), 1656-1662.

Armstrong, Victoria., Barnes, Sally., Sutehrland, Rosamund., Curran, Sarah., Mills, Simon, \& Thompson, Ian. (2005). Collaborative research methodology for investigating teaching and learning: the use of interactive whit board technology. Educational Review, 57(4), 457-469.

Baki, A., Kutluca, T. \& Birgin, O. (2008). Matematik öğretmeni adaylarının bilgisayar destekli eğitime yönelik öz-yeterlik algılarının incelenmesi. VIII. International Educational Technology Conference Bildiriler Kitabı, 6-9 May, 77-81, Anadolu Üniversitesi, Eskişehir.

Bandura, A. (1977). Self-efficacy: Toward a unifying theory of behaviour change. Psychological Review, 84, 191-215.

Baran, E., Chuang, H.H. \& Thompson, A. (2011). TPACK: An emerging research and development tool for teacher educators. Turkish Online Journal of Educational Technology - TOJET, 10(4), 370-377.

Brush, T., Glazewski, K., Rutowski, K., Berg, K., Stromfors, C., Van-Nest, M., et al., (2003). Ntegrating technology in a field-based teacher training program: The PT3@ASU Project.Educational Technology Research and Development, 51(2), 57-72.

Chai, C. S., Koh, J. H. L., \& Tsai, C.-C. (2010). Facilitating pre-service teachers' development of technological, pedagogical, and content knowledge (TPACK). Educational Technology \& Society, 13(4), 63-73.

Christanse, R. (2002). Effects of technology integration education on the attitudes of teachers and students. Journal of Research on Technology in Education, 34(4), 411-434.

Cohen, J. (1988). Statistical Power Analysis for the Behavioral Sciences (2nd ed.). Hillsdale, NJ: Erlbaum.

Çakır, R. ve Yıldırım, S. (2009). What do computer teachers think about the factors affecting technology integration in schools?. Ilkögretim Online, 8(3), 952 964.

Çokluk, Ö., Şekercioğlu, G. ve Büyüköztürk, Ş. (2010). Sosyal bilimler için çok değişkenli istatistik. Tek ve çok değişkenli dağllımlar için sayıltıların analizi, lojistik regresyon analizi, diskriminant regresyon analizi, küme analizi, açımlayıcı faktör analizi, doğrulayıcı faktör analizi, yol analizi. Ankara:Pegem. 
Demiralay, R. ve Karadeniz, Ş. (2010). The effect of use of information and commination technologies on elemantary student teachers' perceived information literacy self efficacy. Kuram ve Uygulamada Eğitim Bilimleri (KUYEB), 10(2), 819-851.

Ekici, E., Taşkın Ekici, F. ve Kara, İ. (2012). Öğretmenlere yönelik bilişim teknolojileri öz yeterlik algısı ölçeğinin geçerlik ve güvenirlik çalışması. Pamukkale Üniversitesi Eğitim Fakültesi Dergisi, 31, 5365.

Erdemir, N., Bakırcı, H. ve Eyduran, E. (2009). Öğretmen Adaylarının Eğitimde Teknolojiyi Kullanabilme Özgüvenlerinin Tespiti. Türk Fen Ĕ̈itimi Dergisi, 6(3),100-108.

Erdoğan N. ve Ader, N. (2013). İlköğretim matematik öğretmen adaylarının bilgisayar destekli matematik öğretimi dersi kapsamında teknolojik pedagojik alan bilgilerinin gelişimi. 1. Türk Bilgisayar ve Matematik Eğitimi Sempozyumu, 20-22 Haziran, KTÜ, Trabzon.

Erdoğan, A., \& Sahin, I. (2010). Relationship between math teacher candidates' technological pedagogical and content knowledge (TPACK) and achievement levels. Procedia Social and Behavioral Sciences, 2(2), 27072711.

Ertmer, P. A. and Ottenbreit-Leftwich, A. T. (2010). Teacher technology change: How knowledge, confidence, beliefs, and culture intersect. Journal of Research on Technology in Education, 42(3), 255-284.

Field, A. (2005). Discovering statistics using SPSS (2nd ed.). London: Sage.

Gable, R. K. (1986). Instrument Development'in the Affective Domain. Boston: Kluwer Nijhoff Publishing.

Gömleksiz, M. N. \& Fidan, E. K. (2011).Pedagojik formasyon programı öğrencilerinin web pedagojik içerik bilgisine ilişkin öz-yeterlik algı düzeyleri. Turkish Studies International Periodical For The Languages, Literature and History of Turkish or Turkic, 6(4), 593-620.

Graham, C. R., Burgoyne, N., Cantrell, P., Smith, L., St. Clair, L., \& Harris, R. (2009). TPACK Development in Science Teaching: Measuring the TPACK Confidence of Inservice Science Teachers. TechTrends, Special Issue on TPACK, 53(5), 70-79.

Gülbahar, Y. (2008). Improving the Technology Integration Skills of Prospective Teachers Through Practice: A Case Study. The Turkish Online Jou nal of Educational Technology-TOJET, 7(4), 71-81.

Hair, J. F. Jr., Black, W. C., Babin, B. J., Anderson, R. E., \& Tatham, R. L. (2006). Multivariate data analysis (6th ed.). Upper Saddle River, NJ: P son/Prentice Hall.

Hatcher, L. (1994). A Step-by-Step Approach to Using the SAS® System for Factor Analysis and Structural Equation Modeling. Cary, N.C.: SAS Institutte, Inc.

Hicks, T. (2006). Expanding the conversation: A commentary toward revision of Swenson, Rozema, Young, McGrail, and Whitin. Contemporary Issues in Technology and Teacher Education, 6(1), 46-55.

Hu, L. and Bentler, P.M. (1999). Cutoff criteria for fit indexes in covariance 
K.Açıkgül,R.Aslaner / Ë̈ Eğitim Fakültesi Dergisi, 17(1) (2015), 118-152

structureanalysis: Conventional criteria versus new alternatives, Structural Equation Modeling. A Multidisciplinary Journal, 6(1): 1-55.

Jang, S.J., \& Tsai, M.F. (2012). Exploring the TPACK of Taiwanese elementary mathematics and science teachers with respect to use of intera tive whiteboards. Computers \& Education, 59(2), 327- 338.

Karal, H. \& Berigel, M. (2006). Yabancı Dil Eğitim Ortamlarının Biliş̧im ve İletişim Teknolojileri (BİT) Kullanarak Zenginleştirilmesi. http://inet-tr.org.tr/ inetconf11/bildiri/56.doc. 11.12.2007 tarihinde alınmıştır.

Kaya, Z., Emre, İ. ve Kaya, O. N. (2010). Sınıf öğretmeni adaylarının teknolojik pedagojik alan bilgisi (TPAB) açısından öz güven seviyelerinin be-

lirlenmesi. 9. Ulusal Sınıf Öğretmenliği Ĕgitimi Sempozyumu, 20-22 Mayıs, Firat Üniversitesi, Elazı̆̆.

Kaya, Z., Özdemir,T. Y., Emre,G., Kaya, O. N.(2011). Bilişim teknolojileri ögretmen adaylarının teknolojik pedagojik alan bilgisi öz yeterlik seviyelerinin belirlenmesi. International Computer \& Instructional Tec nologies Symposium, 22-24September,Firat University, ELAZIĞ.

Kazu, İ. Y. ve Erten, P. (2011). Sınıf öğretmeni adaylarının web pedagojik içerik bilgisine ilişkin görüşleri. 10. Ulusal Sınıf Öğretmenliği Eğitimi Sempozyumu, 57 Mayıs, Sivas.

Koehler, M. J., Mishra, P., Hershey, K., \& Peruski, L. (2004). With a little help from your students: A new model for faculty development and online course design. Journal of Technology and Teacher Education, 12(1), 25-55.

Koehler, M. J., Mishra, P., \& Yahya, K. (2004). Content, pedagogy, and technology: Testing a model of technology integration. Paper presented at the annual meeting of the American Educational Research Association, April 2004, San Diego.

Koehler, M. J., \& Mishra, P. (2005). What happens when teachers design e ucational technology? The development of Technological Pedagogical Content Knowledge. Journal of Educational Computing Research, 32(2), 131-152.

Koehler, M.J., Mishra, P., \& Yahya, K. (2007). Tracing the development of teacher knowledge in a design seminar: Integrating content, pedagogy, \& technology. Computers and Education, 49(3), $740 \quad 762$.

Koehler, M. J., \& Mishra, P. (2008). Introducing TPCK. AACTE Committee on I novationand Technology (Ed.), The handbook oftechnological pedagogical content knowledge (TPCK) for educators (pp. 3-29). Mahwah, NJ: Lawrence Erlbaum Associates.

Koehler, M. J., \& Mishra, P. (2009). What is technological pedagogical content knowledge? Contemporary Issues in Technology and Teacher Education, 9(1), 60-70.

Koh, J. H. L., Chai, C. S., \& Tsai, C. C. (2010). Examining the technology pedagogical content knowledge of Singapore pre-service teachers with a large-scale survey. Journal of Computer Assisted Learning, 26(6), 563-573. 
Koh, J.H.L and Sing, C.C. (2011) Modeling pre-service teachers' technological p dagogical content knowledge (TPACK) perceptions: The influence of demographic factors and TPACK constructs. In Proceedings of ASCILITE Australian Society for Computers in Learning in Tertiary Education Annual Conference, 4-7 December, Australia (pp. 735-746).

Lee, M. H., \& Tsai, C. C. (2010). Exploring teachers' perceived self efficacy and technological pedagogical content knowledge with respect to educ tional use of the world wide web. Instructional Science, 38, $1-21$.

Mahmoud, M.M. and Kamel, M.M.(2010). Using exploratory factor analysis model (EFA) for determination the main factors of train's accidents in egypt (applied study). Applied Mathematical Sciences, 4(38): 1883 $-1897$.

Menard, S. (2002). Applied logistic regression analysis. Thousand Oaks, CA: Sage.

Mishra, P., \& Koehler, M.J. (2006). Technological pedagogical content knowledge: A framework for integrating technology in teacher knowledge. Teachers College Record, 108(6), 1017-1054.

Mutluoğlu, A. ve Erdoğan, A. (2012). İlköğretim Matematik Öğretmenlerinin Tpab Düzeylerinin Farklı Değişkenler Açısından İncelenmesi. 6th I ternational Computer and Instructional Technologies Symposium, 4th - 6th Octaber, Gaziantep University, Gaziantep.

Newsom, J. (2012). Some clarifications and recommendations on fit indices, http://www.upa.pdx.edu/IOA/newsom/semclass/ho_fit.pdf 26.12.2012 t rihinde alınmıştır.

Özsoy, S. ve Özsoy, G. (2013). Eğitim Araştırmalarında Etki Büyüklüğü Raporlanmasi. Illkögretim Online, 12(2), 334-346.

Sancar Tokmak, H., Yavuz Konokman, G. ve Yanpar Yelken, T. (2013). Mersin Üniversitesi okul öncesi öğretmen adaylarının teknolojik pedagojik alan bilgisi (TPAB) özgüven algılarının incelenmesi. Ahi Evran Üniversitesi Kırşehir Eğitim Fakültesi Dergisi (KEFAD), 14(1), 35-51.

Schmidt, D. A., Baran, E., Thompson, A. D., Mishra, P., Koehler, M. J., \& Shin, T. S. (2009). Technological pedagogical content knowledge (TPACK): The development and validation of an assessment I strument for preservice teachers. Journal of Research on Technology in Education, 42(2), 123-149.

Sipahi, B., Yurtkoru, E.S. ve Çinko M. (2010). Sosyal Bilimlerde SPSS’le Veri Analizi. İstanbul: BetaYayınclik.

Şahin, I. (2011). Development of Survey of Technological Pedagogical and Content Knowledge (TPACK). Turkish Online Journal of Educational Technology TOJET, 10(1), 97-105.

Tabachnick, B. G., ve Fidell, L. S. (2007). Using multivariate statistics (5thEd.). Thousand Oaks, CA: Sage Publications. 
K.Açıkgül,R.Aslaner / Ë̈ Eğitim Fakültesi Dergisi, 17(1) (2015), 118-152

Timur, B. ve Taşar, M.F. (2011). Teknolojik Pedagojik Alan Bilgisi Öz Güven Ö çeğinin (TPABÖGÖ) Türkçe'ye Uyarlanması. Gaziantep Üniversitesi Sosyal Bilimleri Dergisi, 10(2):839 -856.

Trigwell, K., Prosser, M., \& Waterhouse, F. (1999). Relations between teachers' approaches to teaching and students' approaches to learning. Higher Education, 37, 57-70.

Tsai, C.C. (2008) The preferences toward constructivist Internet-based learning environments among university students in Taiwan. Computers in Human Behavior, 24,16-21.

Yavuz Konakman, G, Yanpar Yelken, T. ve Sancar Tokmak, H. (2013). Sınıf ö retmeni adaylarının TPAB'lerine ilişkin algılarının çeşitli değişkenlere göre incelenmesi: Mersin üniversitesi örneği. Kastamonu E Ĕgitim D gisi, 21(2), 665-684.

Yurdakul Kabakçı, I. , Odabasi, H. F., Kilicer, K., Coklar, A. N., Birinci, G., \& Kurt, A. A. (2012). The development, validity and reliability of TPACK deep: A technological pedagogical content knowledge scale. Computers \& Education, 58(3), 964-977.

\section{Extended Summary}

\section{Purpose}

The aim of this study was to determine prospective mathematics teachers' confidence level regarding Technological Pedagogical Content Knowledge (TPACK) and to examine whether prospective teachers' TPACK confidence levels differs with respect to gender, grade levels, computer ownership, computer usage frequency and level of technology use.

\section{Method}

This research was designed using descriptive and correlational survey model. The study group consisted of 527 prospective elementary mathematics teachers $($ Female $=355$, Male $=170$ and Missing= 2 ). The data were collected in the Spring semester of 2012-2013 term. In the research data were collected through “Technological Pedagogical Content Knowledge Confidence” scale developed by Graham et al. (2009) and translated into Turkish by Timur and Taşar (2011). The demographic information of prospective mathematics teachers collected through a "Demographic Questionnaire” developed by the researchers. TPACK confidence scale was developed for science teachers related to use of technology in science and technology course. In this study this scale was adapted to mathematics course to determine prospective mathematics teachers' TPACK confidence level related to use of technology in mathematics education. For this reason, exploratory and confirmatory factor analysis was conducted. As different from the original scale, technology knowledge was discussed under two dimensions: Basic Technology Knowledge (BTK) and Advanced Technology Knowledge (ATK). In the data 
analyzes process the descriptive statistic and $\mathrm{F}$ test was used. A result of Bonferroni correction significance level $(\alpha)$ was determined .01 (Abdi, 2010). In addition, the effect size was calculated to reveal the practical significance of the results (Ozsoy and Ozsoy, 2013).

\section{Results}

In the study it was found that prospective mathematics teachers felt quite confident on their TPACK confidence. In the subscales it was determined that they had fairly confident on the TPACK, TCK and ATK subscales and quite confident on BTK and TPK subscales.

The results of the study also showed that the prospective mathematics teachers' TPACK confidence didn't differ with regard to gender. Also, the gender was not a signifance factor in subscales, TPACK, TPK, and TCK, BTK. The only significance difference was in their ATK between males and females. Another similiar result of this study was that the prospective mathematics teachers' TPACK confidence didn't differ with regard to grade levels for all scale and subscales. The prospective teachers' TPACK confidence levels differed significantly between computer ownership and computer usage frequency excluding TCK and BTK. Moreover, the results of the study showed that there were significance difference between level of technology using.

\section{Discussion and Conclusion}

The study results showed that the prospoective mathematics teachers felt quite confidence about their TPACK. When analyzed similar researchs it was determined that teacher candidates who were studying in different departments had TPACK confidence and self-efficacy (Gomleksiz and Fidan, 2011; Kaya et al., 2011; Sancar Tokmak et al, 2013; Yavuz Konokman et al., 2013; Yurdakul Kabakci, 2011). Another results of the study showed that there were no significance difference between gender. This result was parallel to other studies in literature (Akgun, 2013; Gomleksiz and Fidan, 2011; Kaya et al., 2010; Kaya et al, 2011; Kazu and Erten, 2011; Koh and Sing, 2011; Sancar-Tokmak et al., 2013).

One of the results of this research was that there was no significant difference on grade levels. In their study Kazu and Erten (2011) concluded that teacher candidates opinions related to Web Pedagogical Content Knowledge did not differ significantly according to their grade levels. Similiarly the results of the Sancar-Tokmak et al. (2013)'s study showed that there were no significance difference between 2nd, 3rd, 4th grade level teachers candidates in terms of their TPACK confidence. On the other hand, in this study it was found that the prospective teachers' TPACK confidence levels differed significantly between computer ownership in many subscales. Yavuz Konakman et al. (2013) determined that teacher candidates with high levels of access to technology had higher levels of TPACK. The results of computer usage frequency obtained in this study was similar to the results of Baki (2008) and Demiralay and Karadeniz (2010)'s studies. 
K.Açıkgül,R.Aslaner / EÜ Eğitim Fakülttesi Dergisi, 17(1) (2015), 118-152

In this study it was only discussed four of the components in the TPACK framework and not discussed pedagogy, content and pedagogical content knowledge. In this context, developing appropriate data collection tools prospective teachers' content knowledge, pedagogical knowledge and pedagogical content knowledge can be examined. 